\title{
ENTREVISTA
}

\section{MARILENA CHAUI*}

Ent. - Bom, Marilena, a gente queria que, inicialmente, você falasse da sua formação intelectual.

Mar.- Tomando como ponto de partida o curso colegial ou tomando como ponto de partida a Faculdade?

Ent. - Não sei qual a opinião de vocês, eu tenho a impressão que a Faculdade... ou talvez se já no colegial houve um movimento importante para o itinerário intelectual...

Mar. - É, eu gostaria de falar u m pouquinho sobre o colegial, por causa da importância do curso de Filosofia no $2 .^{\circ}$ grau, só por esta razão. Fiz o colegial numa escola pública em São Paulo, considerada na época das melhores do país, o Colégio Presidente Roosevelt da Rua São Joaquim. Quatro professores foram decisivos para minha trajetória intelectual. A professora de literatura, que nos iniciou através de Carlos Drummond e de Guimarães Rosa. O impacto de, aos 16 anos, você lidar com este tipo de trabalho literário foi imenso. A professora de História, que nos fez ler Caio Prado Jr. Foi realmente, para mim, uma verdadeira revolução a descoberta da História do Brasil através da obra de Caio Prado Jr. A professora de latim, com quem se aprendia a ter uma extrema sensibilidade para questões de linguagem lendo Cícero e Virgílio. Acho que o interesse pela linguagem, eu adquiri menos com professores de português e muito mais com o curso de latim. E a figura definitiva, a do professor de filosofia. Esse professor entrou na classe do $1 .^{\circ}$ ano colegial, portanto, numa classe de jovens entre 15 e 16 anos e, sem nenhuma introdução, expôs Heráclito e, em seguida, Parmênides. Fiquei absolutamente fascinada, não tanto porque eu fosse capaz de compreender o significado do que estava sendo exposto, mas por ver, pela primeira vez e em estado puro, o pensamento funcionando. A idéia de que o pensamento trabalha, e trabalha num registro que destrói todas as certezas visíveis, imediatas, foi uma descoberta espantosa. Sobretudo o modo como o professor apresentou os filósofos. Era inconcebível que tudo pudesse ser movimento, pois a sensação da permanência é muito forte e, de repente, alguém, através exclusivamente da operação intelectual, demonstra que tudo é movimento e quando você começa a se convencer dessa mobilidade, você descobre que o pensamento é capaz de trabalhar no sentido inverso e provar que a verdade é a identidade, a imobilidade. Demorou muito tempo para que eu pudesse saber o que isso queria dizer, mas o fascínio, na época, foi descobrir o trabalho do pensamento. Foi decisivo para mim. Houve um tempo em que eu havia pensado em fazer Letras, mas a descoberta da Filosofia mudou meu rumo. À medida que os conteúdos eram trabalhados (tivemos um curso de lógica aristotélica e um curso de história da filosofia, centrado em Sócrates e nos sofistas), as questões existenciais vieram. Tanto as questões religiosas como as questões políticas, que vieram por si mes-

* Departamento de Filosofia - Faculdade de Filosofia, Letras e Ciências Humanas - 05.508 - USP — SP. 
mas, sem que em instante algum o professor João Villalobos tivesse estabelecido para nós correlações, relações desse tipo com tudo aquilo que surgia nas aulas. Era uma maneira que ele tinha de oferecer a filosofia que incentivava os alunos a trabalharem sozinhos, a partir do que ouvíamos. Por isso fui fazer Filosofia. E, ao contrário do que acontece atualmente, os estudantes do $1 .^{\circ}$ ano sentindo enorme decepção quando entram no curso de Filosofia porque este não preenche suas expectativas, essa não foi a minha experiência. Minha experiência foi a de um curso de Filosofia que ampliava os motivos pelos quais eu tinha ido para a faculdade. As questões sobre o funcionamento do pensamento, sobre o trabalho das idéias, sobre a relação da filosofia com os problemas políticos e com os problemas pessoais (embora essa relação nunca fosse explicitamente colocada nos cursos), tudo isso era suscitado pelos cursos. Evidentemente, acho que saí do $4 .^{\circ}$ ano de filosofia com o mesmo sentimento que todo estudante de Filosofia provavelmente tem, isto é, o da dispersão, da fragmentação, a impressão de que, no fundo, você foi informado de muitas coisas, aprendeu certos jeitos de trabalhar, mas não sabe muito bem como coordenar ou unificar tudo aquilo. No meu caso particular, a experiência como professora de Filosofia num curso secundário foi muito importante, assim como foi muito importante porque foi a primeira possibilidade que tive para, sozinha, começar a reunir o que eu havia recebido na faculdade e organizar a minha própria maneira de trabalhar. Acho que não seria possível generalizar, mas no meu caso particular, os instantes de sistematização, de avaliação do significado do trabalho filosófico sempre me vieram através do trabalho como professora mais do que através dos meus primeiros exercícios acadêmicos como o mestrado e o doutoramento. Penso que um trabalho como o da minha tese de livre-docência, e -depois os pequenos textos e conferências que tenho feito, são muito mais resultado de eu ter sido e ser prof essora de filosofia. Para mim, a filosofia tem uma tamanha relação com o falar e o ouvir, tem uma tamanha dimensão de diálogo, de conversa, que é muito por aí que surgem depois as minhas coisas escritas. De alguma maneira, minhas leituras e as leituras que irão desembocar em alguns escritos nascem porque foram antecedidas de conversas.

Conversas que suscitaram o desejo, a necessidade ou a importância de ler e de escrever. Nesse sentido, eu diria que fui muito marcada por minha formação na Universidade de São Paulo. As figuras do Lebrun, como professor exemplar, e do Bento Prado, como o dialogador exemplar, foram decisivas para mim. As aulas do Lebrun e do Bento, que se prolongavam além das salas de aulas (e tinham seus momentos mais altos fora das salas de aulas), marcaram meu modo de me relacionar com a filosofia. Embora eu tenha sido aluna de muitos outros professores e tenha profunda admiração pelo Debrun, pelo Cruz Costa, pelo professor Lívio (tive enormes dificuldades com o Giannotti, quando aluna dele), acho que as figuras marcantes foram as do Lebrun e do Bento. $\mathrm{E}$ a do Bento permanece para sempre, como um horizonte. Depois, já como professora no Departamento, foi grande a importância de Maria Sylvia, que me trouxe algo que eu buscava e era incapaz de encontrar: a possibilidade de perceber a articulação entre Filosofia e História, Filosofia e Política. A presença de Maria Sylvia significou uma virada na minha atividade. Maria Sylvia não tem contemplação, critica até o fim e, no meu caso em particular (como tenho tendências masoquistas), essa crítica não é paralisadora, pelo contrário, é de grande estímulo. Evidentemente, a pessoa mais importante em minha formação é Claude Lefort, não só pela radicalidade de seu pensamento e pela novidade fecunda de tudo quanto ele escreve, mas também pela relação apaixonada com a filosofia que ele herdou de 
Merleau-Ponty. Aliás, eu conhecia Lefort justamente porque meus primeiros trabalhos foram sobre Merleau-Ponty. Com Lefort me foi possível escapar daquilo que uma pessoa como o Bento tinha podido escapar e da qual eu não era capaz de escapar (os meus trabalhos iniciais de História da Filosofia mostram que eu não era capaz de escapar): a perspectiva estruturalista em História da Filosofia, uma certa maneira de lidar com o texto tal que o texto não conduz a nada, senão à monotonia dele próprio. O que descobri no contato, não só com a obra de Claude Lefort, mas no contato pessoal com ele, foi uma outra maneira de me aproximar do texto e que me ajudou a vencer uma oposição insolúvel: o desejo de trabalhar à maneira de Merleau-Ponty, à maneira de Bento Prado e, no entanto, dispondo de técnicas de trabalho contrárias a esse desejo. Acho que os trabalhos iniciais que fiz revelam uma coisa muito curiosa: a técnica de trabalho é estruturalista e a retórica (no sentido pejorativo da palavra) é uma retórica à la Merleau-Ponty. Tentava usar o jeito de Merleau-Ponty escrever, mas trabalhando de uma maneira incompatível com essa escrita. Essa percepção só se tornou clara para mim no contato com Claude Lefort, vendo Claude trabalhar. E trabalhar num campo onde predomina o elemento que me faltava, isto é, a compreensão da natureza específica da coisa escrita. Aprendi muito. Sempre foi dito (dada a extrema importância que o trabalho pedagógico tem para mim) que meus textos eram orais, que eu não escrevia, que meus textos eram falados, coloquiais. Sob esse aspecto, eu devo muitíssimo à Dona Gilda que corrigiu (vezes sem conta) meus primeiros artigos, me mostrou os cacoetes que eu tinha ao escrever, me sugeria jeitos de escrever o escrito. Foi de uma paciência e de uma generosidade incríveis para comigo. Penso que foi no contato com Claude Lef ort que comecei, ainda de uma maneira muito imperfeita, muito iniciante, tateante, a ter uma relação mais escrita com o escrito. Isto para não falar na im- portância política decisiva que ele teve sobre meu pensamento. De alguma maneira, acho que há uma certa continuidade na minha formação, embora marcada por pessoas muito diferentes na sua produção, na sua relação com a política e com a Universidade. Foi um caminho no qual fui descobrindo, de maneira muito lenta, o lastro histórico da filosofia, a dimensão crítico-política da filosofia, a natureza específica da filosofia enquanto escrita e leitura, enquanto discurso e livro.

Ent. - Marilena, seria possível falar um pouco sobre a sua relação com a USP, nos anos em que a sua ligação, inclusive formadora, com ela, foram mais intensas, isto é, os anos 60 ou 70 ?

Mar. - Durante os anos 60 eu falaria um pouco de minha experiência como estudante, minha experiência mais longa enquanto professora é dos anos 70 , porque fui contratada para o Departamento de Filosofia em 66 e em 67 fui para a França e só voltei em 69. Como professora, minha experiência é a experiência da USP após o Ato Institucional n. ${ }^{\circ}$ 5. Como estudante, a USP que conheci era parte da vida da cidade de São Paulo. Não só porque geograficamente ela se situava no ponto de confluência da produção teatral, da produção literária, da produção artística em geral, como ela estava próxima de todas as atividades culturais e políticas. De tal maneira que a sala de aula, o saguão, o pátio do grêmio, o grêmio, os bares, o Teatro de Arena, a cinemateca, a Biblioteca Municipal eram um único espaço. A Biblioteca Municipal era o ponto de encontro, lugar de discussão e lugar de pesquisa. De tal maneira que havia efetivamente uma presença da cidade no interior da Faculdade e da Faculdade no interior da Cidade. Essa experiência é importante para avaliar nosso modo mesmo de viver o período Universitário. As discussões do dia começavam lá na Biblioteca ou na Praça da República e, caminhando, chegávamos até o saguão da Faculdade, e entrávamos para a sala de aula com as 
questões do aiia. Outro aspecto importante era o fato de que, com exceção de um ou outro ramo das ciências exatas, já separados lá na Cidade Universitária (no fim do mundo!), a Rua Maria Antônia era a Universidade de São Paulo. Evidentemente, considerando a Faculdade de Medicina, a Faculdade de Direito e a Politécnica como escolas que não eram exatamente, para nós, a Universidade de São Paulo. A Universidade de São Paulo era a Faculdade de Filosofia, Ciências e Letras, uma Faculdade onde conviviam estudantes e professores de todas as áreas. Tudo funcionava muito e você... Não, não. Era muito curioso, pelo menos para mim, porque não passava muito pela nossa cabeça que houvessem várias Faculdades dentro de uma só. Havia a Faculdade de Filosofia. Aconteciam coisas incríveis. Quando um professor, como o Foucault, por exemplo, foi convidado para dar um curso (o curso foi o manuscrito de "Les Mots et Les Choses"'; fomos os primeiros a ouvir "Les Mots et Les Choses"'), o público era constituído não só pelos professores e estudantes de Filosofia, mas pelos professores e muitos estudantes de toda a área de Humanas (Ciências Sociais, História, Letras, Psicologia), mais o pessoal da Física, o pessoal da Biologia. Eu me lembro, por exemplo, de um simpósio organizado pelo Cruz Costa e pelo Caio Prado Jr. sobre questões de política brasileira. Vejam que tempos: como na Faculdade de Filosofia não havia um anfiteatro suficientemente grande para abrigar todos os que queriam ouvir, esses debates sobre história e política brasileira ocorreram no Mackenzie! O Mackenzie cedeu o anfiteatro para o simpósio. Outro fato significativo. Quando foi levada a peça "A Semente", houve muita polêmica, coisa que "Gimba" e "Eles não usam black-tie" não tinham provocado. No caso de "Gimba" e "Eles não usam black-tie", discutiu-se muito, falou-se muito, eram consideradas uma grande renovação do texto e da montagem. Mas uma peça como "A Semente" suscitou muita polêmi- ca. Houve uma discussão com o Guarnieri e os atores no grêmio da Filosofia, superlotado, e um dos momentos mais altos foi uma discussão, não entre Gianfrancesco e prof essores ou estudantes, mas uma enorme discussão entre Giannotti e uma aluna de Física! Era realmente um ambiente muito peculiar, universitário no bom sentido. Eu me lembro do dia da renúncia do Jânio Quadros. Estávamos na Rua Maria Antônia tomando cafezinho quando veio a notícia. Num primeiro momento, ninguém acreditou e, logo depois, espontaneamente, começaram a surgir na Maria Antônia e dentro do prédio da Faculdade, comícios, discussões políticas. A renúncia do Jânio trouxe para a Rua Maria Antônia pessoas dos mais diferentes lugares, de pontos diferentes da cidade, porque sabiam que lá certamente o fato estaria sendo discutido. Depois, veio 64. Tenho a impressão de que foi a primeira vez que se tornou muito claro para nós todos o que nós éramos. Tenho a impressão de que no momento em que os professores começaram a ser submetidos a interrogatórios no próprio prédio da Faculdade, nas salas da Faculdade, tivemos o sentimento de que se tratava de um acontecimento político no qual a Universidade estava prof undamente envolvida. Era uma evidência que não precisava sequer passar pela reflexão: estava posto, ali, o fato de que militares vinham à Universidade interrogar professores e depois expulsá-los. Eu me lembro também que decidimos resistir, logo depois. Resistir contra o golpe. Foi o momento em que a diferença entre nós e o Mackenzie se tornou explícita. As forças policiais vinham em direção à Maria Antônia para cercar o território. Nós queríamos proteger o edifício da Maria Antônia e tínhamos contra nós a polícia e os estudantes do Mackenzie. (Na ocasião, eu estava grávida de sete meses e segurando os portões da Maria Antônia! Lembro que alguns colegas disseram: "pelo amor de Deus, vai embora porque isso vai ficar horrível"'. E quando comecei a me distan- 
ciar, foi o momento em que ef etivamente os policiais chegaram. E corri, grávida, enorme, corri ouvindo as botas atrás de mim, da Dr. Vila Nova até a Praça da República.) Como não estava no Brasil em 1968 (portanto, esse período é uma verdadeira lacuna para mim, não faço idéia do que foi e como foi), na minha história pessoal o início da destruição da Universidade foi 1964, quando vivi os acontecimentos na sua crueza. A presença dos militares, a presença dos policiais, a expulsão, a resistência, os interrogatórios, o clima de verdadeiro pavor que se instalou, não sei se foi comparável ao que eu vi quando cheguei em 69 . Não creio que seja possível comparar. Se nós pensarmos em termos do que havia sido a USP até o mês de abril de 64 , e o que foram o mês de abril e o mês de maio de 64, eu diria que, politicamente, a violência foi maior do que a de 1968. A de 68 foi primeiro uma violência profundamente policial antes de se instalar como violência política. No caso de 64 , foi imediatamente uma violência política e não era possível distinguir violência policial e violência política. A impressão que, de longe, 68 me dá é que houve duas etapas na violência e na repressão. Em 64, a coisa ocorreu de uma vez só. $\mathrm{O}$ ambiente geral de 68 certamente era mais tenso e grave porque havia guerrilha. Mas em termos puramente "universitários", 64 foi indescritível porque inimaginável em São Paulo. Inesperado demais. A Faculdade que encontrei quando cheguei em 1969 era outra, era um conjunto de professores e de estudantes dispersos em barracos no Campus da Cidade Universitária, completamente desarvorados, com a sensação de que era preciso resistir, mas não se sabia muito bem como resistir, nem contra o que resistir. O que encontrei foi uma escola inteiramente nova, inesperada, que não tinha nada mais, absolutamente nada mais a ver com aquela que eu tinha conhecido nos anos 60 . Talvez, se eu tivesse vivido o desenrolar dos acontecimentos em 67, 68 e no início de 69 , a transformação não fosse sentida por mim de uma maneira tão brutal. Não sei. Mas para quem chegou à Cidade Universitária no ano da graça de 1969 , a sensação era a de terra arrasada, de fim de uma época e, naquele momento, a expectativa do nada. A sensação de que nós estávamos ali por uma certa inércia, mas sem nenhuma justificativa. Levou um certo tempo para ir ficando claro que havia motivo para ficar lá, que era importante ficar, que ia se iniciar um período de resistência política e cultural. Na minha experiência, foi esse período, especialmente 0 período que vai até 78 , o tempo no qual, pelo menos na área de Humanas, o movimento estudantil foi a força universitária efetivamente existente. Acho que devemos aos estudantes a existência da Faculdade. Ao mesmo tempo em que o esforço de alguns professores foi gigantesco, porque era o momento no qual você entrava para dar aula sabendo que havia na classe policiais, que o DOPS estava lá registrando. Sabíamos que havia microfones nas salas dos professores, que funcionários eram espiōes, que havia "estudantes" encarregados de apresentar relatórios de nossas atividades. Sabíamos que os estudantes eram vigiados, que nossos passos, fora e dentro da Faculdade, eram vigiados. Trabalhávamos não sob tensão mas sob terror, e um terror ilocalizável, porque a repressão podia vir do colega (como veio para muitos), dos alunos (como veio para muitos), como podia vir de um desconhecido que tinha se plantado lá. Quantos professores foram presos, interrogados, por denúncias de estudantes? Perdemos a conta. Quantos professores foram expulsos por denúncias de colegas e quantos estudantes foram presos e torturados por denúncia de seus colegas? Perdemos a conta. Nenhum de nós sabia se haveria dia seguinte. Trabalhávamos o tempo todo na expectativa ou da prisão ou da expulsão, os passaportes prontos, sabendo que a correspondência e os telefones eram controlados. Quando olho para trás, a 
sensação que tenho é muito estranha: tenho a sensação de um pesadelo. É muito difícil acreditar que foi real e, ao mesmo tempo, tenho um outro sentimento, que também é de irrealidade, mas oposto e que me faz perguntar: como foi que sobrevivemos? De onde foi que tiramos força para sobreviver? E não sobrevivemos de uma maneira qualquer. No caso particular do Departamento de Filosofia, uma revista foi criada (por Dona Gilda), teses foram feitas e defendidas, o Departamento foi reestruturado, uma pós-graduação foi criada, e os cursos de Graduação foram inteiramente reformulados, com a participação intensa dos estudantes. No meu caso particular, a possibilidade de uma outra perspectiva pedagógica, de trabalhar a filosofia de uma outra maneira, não partiu de mim, partiu dos estudantes com os quais convivi. Foram eles que criaram outras possibilidades de trabalho. E tudo isso sob as ameaças ininterruptas das torturas e dos exílios. No Departamento de Filosofia conta-se nos dedos quem não teve essa experiência. Aqueles que não tiveram experiência direta da prisão, que não tiveram a experiência do exílio, que não passaram pela experiência da cassação, tiveram a experiência dos interrogatórios. Cada um de nós, estudantes e professores, vivemos sob esse clima. Por isso eu me pergunto: como foi possível termos feito tudo que fizemos? Para mim é um mistério. Acredito que, em parte, era a profunda convicção política que sentíamos de que não era possível permitir que um mínimo de produção cultural e de trabalho de pensamento pudesse ser destruído, que não podíamos permitir que o obscurantismo mais profundo imperasse no país. Tenho a impressão de que foi um momento muito claro de decisão, sem nunca ter sido verbalizado por nenhum de nós, nem professores nem estudantes. Tenho a impressão de que era muito claro para nós que não estávamos na defesa de um patrimônio nem de uma tradição (nós tínhamos críticas profundas à própria
Universidade), que não estávamos preservando um bem acima do mal (muito pelo contrário, nós tínhamos críticas profundas a tudo), mas havia a idéia de que não era possível permitir a destruição de um trabalho cultural que, a longo prazo, seria fundamental. A lembrança que tenho dos anos 70 é a da experiência inicial da resistência e, depois, de uma maneira muito lenta, a do surgimento de alguns pontos (eu me refiro particularmente ao Departamento de Filosofia), de uma perspectiva, que não era apenas a perspectiva da resistência nem só a perspectiva da crítica, mas também o sentimento de ter algo novo para mostrar. Acho que muitos trabalhos que começaram a desabrochar, eu diria de 77 em diante, revelam que havia coisas novas, maneiras novas de trabalho. Foi uma experiência ao mesmo tempo complicada porque nosso esforço para preservar o trabalho teórico foi tão intenso que não nos demos conta de um acontecimento fundamental porque estávamos muito ocupados com o elemento policial repressivo que estava na nossa mira porque nós estávamos na mira dele. Não nos demos conta do que estava ocorrendo com a própria estrutura da Universidade. Demorou para percebermos que ela tinha sido "modernizada", que tinha sido realmente transformada numa rígida estrutura burocrática. Não que a Universidade não fosse hierárquica (esta era uma das grandes discussões do nosso tempo, nos anos 60), mas a natureza da hierarquia mudou, tornou-se a hierarquia moderna, isto é, invisível, impessoal, administrada. De repente, nós nos demos conta de que estávamos inteiramente regulados de fora desde o trabalho pedagógico, as horas de aula, os currículos, o curso semestral, o número de alunos em classe, os créditos, a forma de avaliação, e a nossa própria carreira. Tenho a impressão de que foi uma das maneiras mais sutis para transformar a Universidade sem que seus membros se dessem conta porque estavam efetivamente sob o tacão do terror. Foi uma verda- 
deira pérola histórica o que foi feito conosco, porque nossa atenção ficou de tal maneira concentrada sobre o perigo policial repressivo, sobre a triagem ideológica e sobre a necessidade de uma produção cultural que não se curvasse à ditadura, que não percebemos o exercício invisível da ditadura dentro da Universidade. A ditadura nos aparecia no instante em que um professor não era recontratado, no instante em que um professor era preso, no instante em que um aluno era torturado. Nesses instantes, a ditadura aparecia para nós. E não a vimos na forma ef etiva pela qual realizou a transformação da estrutura da Universidade. Não acho que tenha sido casual o aparecimento do tema da redemocratização da Universidade (embora eu tenha restrições a esse prefixo, ao prefixo re, porque eu me pergunto quando foi que tivemos uma Universidade democrática). E é possível notar os limites que a estrutura universitária impôs à própria idéia de democracia universitária. Quando analisamos nossas reivindicações no plano de uma democratização, essas reivindicações são extremamente limitadas, concernem apenas à tentativa para minimizar os ef eitos de uma estrutura excessivamente autoritária. Provavelmente o que passa pela nossa cabeça é que é preciso primeiro fazer essas pequenas modificações para depois democratizarmos efetivamente. Em todo caso, o que mais me impressiona é a eficácia com que a ditadura fez uma reforma universitária sem que a percebêssemos. Talvez por isso nossa redemocratização seja tão limitada.

Ent. - Agora, uma questão que me interessa, Marilena: até que ponto desse engodo, por assim dizer, em que nós nos deixamos todos envolver, em nos sensibilizarmos mais à flor da pele, pela violência imediata verificada na repressão policial, não perceber a insídia, dessa reforma ou da modernização burocratizante da Universidade, mas até que ponto, nós, muitas vezes, entramos, principalmente em termos de produção. Quando a pesquisa en- tre os anos 70 de repente estava fazendo esse jogo, com as exceções, felizmente brilhantes, pode-se dizer que uma margem expressiva das produções intelectuais estava dentro deste jogo.

Mar. - Acho que você tocou num ponto essencial.

Ent. - Talvez muito doloroso...

Mar. - Ah! Terrível, terrível, que a gente gostaria de apagar, ficar apenas com a imagem heróica da resistência, mas acho que esse ponto é fundamental. Não só a nossa cumplicidade com a reforma da Universidade, mas sobretudo o fato de que a grande maioria dos professores desejou essa reforma. Acho que essa reforma foi desejada pelos que viram através dela a possibilidade de ocupar postos de decisão dentro da Universidade. Pactuaram, estimularam e trabalharam em favor dessa reforma porque ela os beneficiava em termos de poder e de prestígio. Houve também cumplicidade ao estabelecer critérios exteriores à própria produção intelectual para avaliá-la. Quando esses critérios (prazos, créditos, relatórios, provinhas) foram impostos, tocou-se na própria natureza das pesquisas, fazendo-as homogêneas ou semelhantes, desconsiderando a área em que a pesquisa é feita, suas dificuldades específicas, seu sentido próprio. Tudo se reduziu ao rendimento, à produtividade e à eficácia, como na linha de montagem. Lembro-me de haver participado de um debate promovido pela ADUSP no qual estava presente o Prof. Crodovaldo Pavan, que insistia na racionalidade, na objetividade, no valor desses critérios para medir o rendimento, a produtividade, a seriedade e a honestidade dos pesquisadores. Quando eu disse a ele: "Professor, além de eu considerar todos esses critérios condenáveis porque são medidas extrínsecas ao trabalho intelectual, o Senhor também precisa levar em conta que os diferentes campos da pesquisa possuem seus tempos próprios e se é possivel (não sei porque não conheço), mas se é possível ao pesquisador que trabalha no 
laboratório com o microscópio efetuar sua pesquisa em dois anos e apresentar os resultados em dois anos, em Filosofia, uma pesquisa séria, uma pesquisa consistente precisa de 10 anos." A resposta foi fantástica: "Enquanto os filósofos ficam germinando idéias que jamais apresentam, o restante dos professores e pesquisadores da Universidade sustentam a preguiça." Lembro-me de ter ficado muito zangada e ter-lhe dito que não concordava com uma visão stakanovista da produção teórica, que achava muito estranho que ele estabelecesse como relação entre colegas a diferença entre os operosos e os preguiçosos, portanto, uma distinção moral e não uma distinção intelectual. Esse debate foi muito elucidativo para mim porque há duas faces muito estranhas nessa questão. De um lado, existe a idéia de que a Universidade só é útil se for possível estabelecer, a cada passo, o quanto ela é produtivamente eficaz. Pelo cômputo das horas/aulas, das horas/créditos, dos títulos, mede-se a utilidade da Universidade que, por ser útil e ter essa utilidade visualizada quantitativamente, é honesta. E porque a Universidade é honesta, cabem-lhe certos direitos. Há todo esse lado profundamente protestante, moralista e, ao mesmo tempo, muito moderno: a quantidade mede a virtude, e à virtude direitos são concedidos. Mas, há uma segunda face, muito curiosa. Para muitos, que querem manter o valor intrínseco do trabalho intelectual, parece que não apresentar jamais trabalho algum vira prova de seriedade intelectual. Esse lado é que mais me impressiona. Que o outro lado seja coerente e diga: a tantas horas de pesquisa correspondem tantas páginas, a essas tantas páginas correspondem tantos créditos, a esses tantos créditos corresponde o título, parece muito coerente. $\mathrm{O}$ que é extremamente curioso é uma defesa do trabalho intelectual sob a condição expressa de que ele nunca tenha frutos. Ou melhor, que se ele produzir frutos, isto será um sinal de falta de seriedade. $\mathrm{O}$ moralismo está presente nos dois lados. O moralismo funciona para avaliar os "operosos" contra os "preguiçosos", mas funciona também do lado oposto ao se considerar que o fato de haver um trabalho feito é prova de falta de seriedade. Criam-se dois lados: um, que é cúmplice (se não realizador efetivo) do projeto governamental, e outro que afirma opor-se a isto. Mas o campo da adesão e o campo da oposição, em qualquer assunto (salário, democracia, produção teórica, forma da pesquisa) tem sempre como referenciai da discussão o tempo. Um lado quer produção em tempo curto; o outro usa o tempo longo para combater a existência de trabalhos teóricos efetivos. Um lado afirma alguma coisa e o outro simplesmente faz essa mesma afirmação de ponta-cabeça. Não há um esforço para ultrapassar o quadro de referências dado. Você se opõe, mas se mantendo dentro do mesmo campo. Assim, contra o moralismo operoso surge o moralismo da não apresentação dos trabalhos. De um lado, o elogio do stakonovista, e do outro, o elogio do sábio, cujo silêncio é a prova de sua sabedoria. Esse elogio do sábio silencioso me faz sempre pensar num conto de Machado de Assis sobre um sujeito que era tido como gênio porque em todas as discussões sempre tinha um ar muito circunspecto, nunca dizia nada. Muitos anos depois, quando morreu, descobriu-se que ele tinha um dente cariado e que passava o tempo todo com a língua brincando com o buraco da cárie. Por isso não falava. Seu silêncio, sempre tomado como altíssima sabedoria, o fazia ser periodicamente considerado juiz das idéias dos outros, sem que ele nada tivesse a dizer. O simples silêncio o transformava em juiz da palavra do outro. E ele estava simplesmente brincando com a cárie.

Ent. - Ficando no campo da Universidade ainda, nós tínhamos preparado três perguntas que eu acho que você respondeu. Talvez possa especificar a partir delas então, de uma maneira que seria aproximadamente o seguinte: pode o professor universitário, empenhado na produção do 
saber, ser ao mesmo tempo burocrata? Ou: qual a relação que a gente poderia estabelecer entre aquilo que - para usar um termo que nós encontramos em determinadas obras - uma formação moral e intelectual do professor e a sua atividade enquanto funcionário público? E a outra pergunta que seria neste sentido também é: como se faz hoje a computação do intelectual. Suponho que a sua resposta anterior tratou disso, algum viés específico que poderia...

Mar. - Respondo negativamente à primeira pergunda. Acho que há uma incompatibilidade de essência (no sentido fenomenológico, aristotélico, espinosano) entre o burocrata, o professor e o intelectual. Por um motivo muito simples. É que os afazeres do burocrata são de tal natureza que são afazeres cujo pressuposto é que ele deva abandonar o ato de pensar. Não é possível um burocrata pensando. Ou ele pensa ou ele é burocrata porque (sem precisar ir à análise marxista da burocracia, nem à análise lefortiana da burocracia ou à análise de Castoriadis, ficando só com a análise weberiana) a racionalidade da burocracia está no fato de seus membros, uma vez tendo demonstrado através de provas que estão habilitados para o posto, tudo o que tinham a pensar, já pensaram. A partir da inserção burocrática têm que realizar a rotina, a ordem. Uma experiência antiburocrática foi tentada em nosso Departamento de Filosofia, mas, infelizmente, abortou. Em 69, o Departamento de Filosofia corria o risco de ser controlado por um interventor porque, após as cassações, os professores não tinham os títulos necessários para que o Departamento fosse considerado um Departamento. Como havia o risco do interventor, alguns de nós, primeiro Maria Sylvia e depois eu, apresentamos nossas teses para que o Departamento tivesse os títulos necessários e não ficasse sob interventoria. Colocou-se, então, a questão da Chefia do Departamento. Elegemos Maria Sylvia, mas com o compromisso de divi- dirmos as tarefas, isto é, Maria Sylvia não ia ser transformada numa burocrata para salvar o Departamento de Filosofia. As tarefas da burocracia iriam ser inteiramente parceladas, divididas e distribuídas para que, cada um se ocupando de uma fatia dela, minimizasse a própria burocratização. Ao mesmo tempo, o que era fundamental nisso era o fato de que todos, colaborando, dividindo esse trabalho, um na Congregação, o outro no CID, o outro na secretaria do Departamento, o outro na direção das reuniões, o outro cuidando da Graduação, o outro cuidando da PósGraduação, cada um de nós participava efetivamente da direção do Departamento. Havia uma direção ef etivamente colegiada. Infelizmente essa experiência não pôde ser prosseguida. O Departamento paulatinamente se deixou devorar pela burocracia. O burocrata, o professor e o intelectual são figuras incompatíveis, mas a burocracia pode ser contornada se você espalhar o trabalho burocrático entre todas as pessoas, de tal modo que cada uma se encarregando de uma fatia, ao mesmo tempo ajuda a conduzir os trabalhos e nenhuma delas é absorvida pela máquina. E você burla a intenção da burocracia que é a hierarquia.

Ent. - Eu me lembro que era aluno naquela época e me lembro que, da parte disso que você chama de burocracia, que tomou conta do Departamento de Filosofia, ficou muito claro, para os alunos, que a grande crítica feita a esta cogestão era a ineficiência, quer dizer então, eu me lembro do discurso em que era explicado com toda pedagogia aos alunos, que a bagunça do Departamento de Filosofia se devia à ineficiência desse colegiado. Quando se aludia que a bagunça vinha, se mostrou que era resultado de um desmantelamento de um Departamento etc.etc. Era um trabalho da ditadura como você mostrou, quer dizer então que a burocracia ela cumpriu papel político de - talvez consciente, talvez inconscientemente - realizar um trabalho. Quer dizer, esse fantasma 
da ineficiência - nada dá certo. O democrático só leva à anarquia. Então a experiência de democracia foi abortada de um lado, pela própria situação mais ampla de recessão e foi incentivada de dentro, foi finalizado com essa palavra de ordem vamos regularizar, vamos racionalizar etc....

Mar. - Vamos ser eficazes, competentes...

Ent. - Vamos ser eficazes, competentes, exato. Como aluno deu para acompanhar muito bem esse tipo de mudança, a partir da qual, por exemplo, os créditos foram racionalizados e encavalaram-se os regimes de alunos. Aí começou o drama dos cálculos.

Mar. - O discurso sobre a reorganização do Departamento era poderoso não só porque efetivamente o Departamento tinha ficado completamente destroçado com os acontecimentos de 69 e essa reorganização aparecia como um discurso plausível, mas também porque ele solapava, efetivamente, o caráter democrático do Departamento. E mais. O que nós tentamos, no início, foi não submeter nosso trabalho a toda imposição burocrática que tinha sido feita. A questão dos créditos, das horas/aula, tudo isso era inteiramente alheio às nossas atividades. No momento final, lá nos papéis, se produzia isso. Mas isso não se passava pelo nosso trabalho ef etivo. Ouvi algumas vezes ser dito que nós estávamos burlando a legislação universitária e que se fosse feita uma devassa no Departamento de Filosofia, este seria fechado. Com isso, não se queria admitir que nós estávamos desmantelando um projeto de burocratização. O que surgia era a idéia de que nós não estávamos cumprindo a lei e que iríamos pagar por isto. E mais. Era dito que se acontecesse alguma coisa, o Departamento iria pagar pela irresponsabilidade de alguns.

Ent. - Esse quadro de burocratização também se estabeleceu no regime da propriedade dos títulos acadêmicos. É algo importante que ocorreu nesse regime de burocratização, porque um compromisso ficou claro - um compromisso solene do Departamento de Filosofia, porém político - foi que, uma vez cassados o Bento Prado e o Giannotti, não se fariam concursos, não se abririam as vagas para os professores titulares do Departamento, enquanto esses professores não voltassem. Esse compromisso foi cumprido rigorosamente por alguns, mas, num determinado momento esse quadro burocrático rompeu o compromisso e houve então candidaturas ao cargo de titular, o que colocou o Departamento dentro da "normalidade". Definitivamente dentro da "normalidade"'. De tal modo que, quando houve a anistia, tanto o Bento Prado quanto o Giannotti encontraram, de fato, um outro titular. Uma coisa extremamente pesada, do ponto de vista político.

Mar. - E um outro compromisso que o Departamento tinha e que seguiu à risca anos a fio era o de que título não definia coisa alguma. Nõ era por título que alguém dirigiria o Departamento, não era por título que alguém convidaria pessoas a virem ao Departamento, não era por título que alguém participaria ou não de Bancas, não era por título que o Departamento seria regido. Era um colegiado efetivo, um colegiado para contratação e recontratação, um colegiado na Direção, na escolha e na discussão do tipo de articulação entre os diferentes cursos. Houve um momento em que trabalhavam em condição de igualdade com uma mesma classe um professor com o título $\mathrm{X}$, outro professor com o título $Y$, outro professor sem título e alunos na qualidade de monitores. De repente, esse Departamento incorporou a titulação como pré-condição para tudo. A partir de um determinado momento, o título começou a valer e desde então o colegiado se tornou uma farsa muito triste porque, no fundo, como o título determina a participação nos demais colegiados da faculdade, os outros professores estão excluídos das decisões. 
Anteriormente, cada um de nós, por rodízio, tinha acesso à Congregação, ao CID, à Diretoria, às diferentes comissões, participava da comissão de Graduação, da comissão de Pós-Graduação, tudo por rodízio: Estávamos todos razoavelmente familiarizados com o funcionamento da faculdade. A partir do momento em que o título define o posto e a direção, nós temos um único indivíduo que faz parte de todos os colegiados.

Ent. - Quando não é de situação, Marilena, está ocorrendo uma outra coisa a nível do microfoguete do Departamento, etc., que é uma perversão, um rebaixamento, por inversão, por apresentação às avessas, da função do burocrático. Isto é, manipulando-se agora a co-gestão e a administração colegiada, se passa, se pulveriza, se atomiza a burocracia, mas que insidiosamente leva sua função paralisadora do pensamento e da produção. Então, esta é uma função nova, é uma versão de uma situação nova que precisa ser denunciada. É a mesma interponente função paralisadora, esterilizadora do burocrático, travestida de participação.

Mar. - Isso é nítido, por exemplo, quando você toma o papel das mais variadas comissões. E, aparentemente, uma Comissão é um lugar de participação. Na verdade, ela está ditando regras burocráticas do funcionamento da Universidade e decidindo o destino profissional e pessoal de cada um de nós.

Ent. - Ou seja, se escarra nas nossas caras e se ri nas nossas costas.

Mar. - Exatamente, somos esbulhados de toda maneira.

Ent. - Eu me lembro, tem outro lado também da coisa, Marilena, que foi agravado com esse protesto de burocratização. Foi também o acentuar-se diante da divisão social do saber. Eu me lembro que Maria Sylvia Carvalho Franco, que fazia até então parte do departamento de Filosofia, solicitou a passagem de admissão, foi-lhe dito, de público, que ela não tinha direito, que era uma usurpação, porque ela não tinha o diploma de Bacharel em Filosofia. Ora, esse tipo de raciocínio pode ser levado ao absurdo, colocaria para fora do Departamento de Filosofia, o Departamento de Filosofia. Porque, na realidade, a estrutura, o pensamento, o projeto que apresentou, como você mostrou, como não-alternativa, mas como tentativa de salvar o que havia de universalizante na Maria Antonia, era essa indisciplina, essa passagem, e justamente, quanto mais, suponhamos, um sociólogo, um historiador, etc., se aproximava do saber filosófico, mais bem-vindo, com todas as brigas, as diferenças, os questionamentos, das competências, mas isso é normal. Agora, jamais havia sido utilizado o argumento do diploma, do carimbo em cima, nunca. Foi a partir desse momento que isso começou a vigorar, como se, suponhamos, um excelente pintor, não pudesse jamais se tornar um filósofo. No caso, por exemplo, o Leonardo da Vinci não seria adjunto do Departamento de Filosofia, quer dizer, mais ou menos isto.

Mar. - Esse processo é grave em vários níveis. É grave historicamente porque um Departamento de Filosofia deve a duas mulheres não bacharéis em Filosofia a sua existência. Ele deve a duas sociólogas a sua existência, isto é, à Dona Gilda e à Maria Sylvia. Então, a dívida histórica que o Departamento de Filosofia tem com o "não-filósofo" é enorme. No momento em que era para preservar o Departamento de Filosofia para que houvesse continuidade do trabalho, elas foram reconhecidas, mas sempre com ressalvas de alguns. No caso de Dona Gilda, além de manter o departamento funcionando, ela criou a revista "Discurso", e me lembro de um professor, que esteve fora durante os anos negros, ao chegar e ver o primeiro número da revista, em vez de comemorar e celebrar, como nós estávamos fazendo, considerou a revista medíocre. Isso é uma coisa que não vou perdoar nunca, porque 
produzir essa revista naquelas condições havia sido enorme. Foi uma injustiça flagrante. No caso da Maria Sylvia, a coisa foi muito grave. Maria Sylvia escreveu um trabalho que ela nunca publicou porque não era o trabalho que ela queria fazer, mas que fez para o Departamento de Filosofia sobreviver, sacrificando um livro numa tese acadêmica. Quando, anos depois, ela quis fazer o concurso para professor adjunto, alguns alegaram que era impossivel porque ela não era bacharel em Filosofia. Além da injustiça patente, também houve desconsideração pela trajetória intelectual de Maria Sylvia, que cruzara com a filosofia e fizera muitos de nós cruzarmos com a história e a política. Numa ocasião em que o diálogo entre pessoas com formação diferente acontecia e produzia trabalhos, isso foi considerado irrelevante em nome da burocracia e dos títulos. Quando um Departamento de Filosofia é capaz de desconsiderar uma trajetória intelectual, você se pergunta o que aconteceu com esse Departamento. No tempo de Cruz Costa, Lívio Teixeira, Bento, Giannotti, Rui Fausto e Porchat, cada um de nós não era considerado especialista; fazíamos nossas teses buscando o que havíamos escolhido, mas, como professores, éramos professores do Departamento de Filosofia. Cada um de nós era considerado capaz de ministrar cursos nas diferentes disciplinas, que era importante para o nosso trabalho pessoal, como era importante para os alunos perceberem que diferentes pessoas podiam trabalhar sobre dif erentes assuntos. Isso foi paulatinamente sendo destruído. De alguma maneira, o Departamento de agora se reparte em especialistas. É verdade que através das disciplinas optativas contornamos um pouco isto. Mas, de algum modo, cada um de nós acaba tendo sua cadeira cativa, destruindo um estilo do Departamento, onde o Bento dava aula de História da Filosofia, como de Ética ou de Estética; o Giannotti dava aula de Lógica, de História da Filosofia; o Lebrun dava aula de
Lógica, de História da Filosofia, de Ética, de Teoria do Conhecimento.

Ent. - E que se refletia na produção pública, por exemplo, o Bento, me lembra sobre o Guimarães Rosa, por exemplo, você não sabe dizer, até que ponto aqui da História da Filosofia, aquilo é crítica literária, aquilo é, a produção era universal, quer dizer, se respeitava o Universal. Então não se catalogou o texto do Bento, contra isso, isso é um texto de Filosofia, ponto. Porque o juízo que aparentemente é um elogio, é limitativo. Marilena, uma pergunta muito simples: O que mudou? No seguinte sentido: tem-se conseguido recentemente, depois dos anos 70 para cá, o desmembramento ou a ampliação do que era antigamente a cadeira ou disciplina de Ética; ou, às vezes, Ética e Filosofia Política, em Ética, uma disciplina, e Filosofia Política, outra. No entanto já começam a despontar certas reações, para não dizer, certas resistências que, com um discurso muito curioso, dizem, examinando de um lado filosófico, entre aspas, por outro lado, o político, sempre entre aspas também, que já se está fazendo mais política do que filosofia.

Mar. - Exatamente.

Ent. - Então, volto à face mais externa da pergunta. O que mudou entre 70 e 80 ?

Mar. - Acho que o que mudou profundamente foi o aparecimento de algo que está em gestação, uma descoberta. De repente, nós que fazemos filosofia percebemos que dispomos de um acervo teórico, de um instrumental de trabalho que nos tornam capazes de fazer aquilo que a filosofia sempre fez: refletir sobre as experiências de seu próprio tempo. Acho que o que surge não é a idéia de engajamento, nem a idéia do nacional, nem a idéia do populismo, nem do vanguardismo, mas a percepção de que estamos conceitualmente preparados para tratar do nosso presente no campo político, no campo artístico, no campo social, no campo da produção científica existente no Brasil, enfim, que é 
possível um trabalho de reflexão cujo suporte é o nosso contacto com a História da Filosofia e o nosso contacto com a trajetória das disciplinas filosóficas. Tenho a impressão de que há uma espécie de interesse filosófico na compreensão da realidade e das ilusões presentes. A experiência dos anos 70 deixou claro para nós que se você se exime de uma reflexão sobre o mais banal cotidiano, uma explosão na casa de Detenção, a censura de um filme, o surgimento de um romance inteiramente novo, um ato explícito de violência, se você se exime de uma reflexão a esse respeito, pelo seu silêncio mesmo, você está fazendo o serviço do autoritarismo e da repressão. De alguma maneira, o que amadureceu para alguns de nós, ao fazermos a crítica do nacionalismo e do populismo, foi uma reflexão sobre o Brasil sem precisarmos proclamar a necessidade de uma filosofia "nacional". Acho que porque foi possível passar pela crítica de determinadas ideologias é possível uma reflexão sem aqueles compromissos que foram tão pesados e que faziam com que, no passado, para evitar o nacionalismo, o populismo, e para evitar a paralisação, quem fazia filosofia, quando se voltava para alguma coisa no Brasil, se voltava para cá em instantes muito esporádicos. Era o Bento analisando Guimarães, era o Lebrun falando do ISEB, era Rui Fausto analisando as posições de Oliveiros ou a obra de Caio Prado, eram textos muito esporádicos. Deixava-se de lado o Cruz Costa e a preocupação com as idéias no Brasil. Houve o esquecimento do trabalho do Cruz Costa, que ficou sem continuação. Quando eu digo sem continuação não digo que seria preciso continuar fazendo o mesmo trabalho que ele fez, mas conservar a intenção filosófica e histórica que ele tinha.

Ent. - Marilena, chegou no ponto de minha pergunta...

Mar. - Eu só queria fazer uma pequena observação. É evidente que se aquilo sobre o que você exerce a sua reflexão for alguma coisa que não foi pensada ainda, você tateia, apresenta suas idéias, mas sob a forma provisória, você vai, volta, muda, reformula, faz o caminho. Ora, o fato de que você tenha consciência da fragilidade do que você está fazendo não costuma ser visto como uma fragilidade a ser respeitada, mas como uma fragilidade a ser atacada. Um bloqueio a seu esforço. Neste ponto, sou muito merleaupontyana. No "Elogio da Filosofia", MerleauPonty pergunta: quando Galileu estava sendo julgado pelo Santo Ofício, por que Descartes não se pronunciou? E mais. Por que não se pronunciou contra os teólogos? Os acadêmicos dirão que Descartes é um filósofo justamente por não tomar partido, pois a filosofia lida com o absoluto e o absoluto não toma partido. Ora, retruca Merleau-Ponty, quem assim pensa estar elogiando Descartes, simplesmente o está colocando fora da filosofia, fazendo da filosofia um mito, esquecendo-se de que ela está mergulhada nos erros do século. Não tomar partido é não fazer filosofia. E ainda porque sou merleaupontyana me referi à fragilidade do que vamos pensando e escrevendo. Merleau-Ponty escreve que o filósofo é aquele que é testemunha de sua própria desordem interior. De modo que a crítica "ordeira" que anda por aí, que não suporta a desordem interior nem que você exponha, no sentido amplo da palavra, essa desordem, me parece um traço do autoritarismo nacional que agarra quem faz filosofia, como agarra toda tentativa de pensamento.

Ent. - Então, Marilena, já que está na exposição, eu poderia mostrar as confissões de Santo Agostinho no Livro 15, Capítulo 11, que é o seguinte: Quem nos autoriza a afirmar que o tempo é, é que ele tende a não mais ser. Analisando o seu trabalho, procurando o seu trabalho, aquilo que, evidente, tem um peso, uma manifestação filosófica que não lhe é negada, eu tenho notado que, tanto nas aulas, me lembro que o primeiro ano de filosofia que eu tive com você, uma das coisas que mais me marcou foi a atenção que vo- 
cê tinha do problema do texto, do texto do filósofo. Você se lembra ainda da era o Kirkergaard, onde você mostrava as variações do tempo no texto escrito. As suas aulas, no primeiro Merleau-Ponty, no primeiro Espinosa, sobretudo no segundo Espinosa, nos artigos de ciscunstância por exemplo três em uma, que aparentemente é uma viagem, que é um percorrer do espaço, mas é justamente uma reflexão sobre o surgimento da teoria do tempo moderno, você tem se interrogado sobre esse permanente e esse transitório e aí eu perguntaria: Por que Espinosa?

Mar. - Eu diria que o motivo inicial da escolha de Espinosa é filosófico, mas é um filosófico quase entre aspas. É autobiográfico, eu diria. Vim de uma formação religiosa ao mesmo tempo católica ultramontana e mesclada com um catolicismo sincrético, onde o elemento mágico estava muito presente. A formação católica ultramontana me colocou sempre diante de um problema: da culpa pela liberdade. Como é que você pode ser culpado da liberdade? E mais. Se Deus é um juiz onisciente e onipotente, uma exterioridade absoluta, por que Ele nos julga pelo que já sabe que iremos fazer? De alguma maneira, a eternidade do Deus-juiz e a temporalidade da minha liberdade culpada era um problema insolúvel, com e sem sentido. De outro lado, nos instantes de desespero e angústia, o recurso a todos os elementos mágicos era indispensável para o apaziguamento interior e garantia de certezas. Por acaso, durante um curso de História da Filosofia Moderna do Prof. Lívio Teixeira sobre Espinosa, quando ouvi exposição sobre o Deus de Espinosa, eu me lembro de ter tido uma reação que, hoje em dia, em nossas classes é perfeitamente natural, mas que naquela época foi uma coisa um tanto chocante. Eu me lembro que, do fundo da classe, gritei: "Prof essor, eu procurei isso a vida inteira!' A filosofia de Espinosa foi a descoberta de que era possível a liberdade sem culpa. Mas achei que era incapaz de enfrentar a filosofia de
Espinosa, absolutamente incapaz. Também por acaso, algum tempo depois, abri o “Tratado Teológico-Político" e descobri a relação entre o medo, a esperança e a superstição. Compreendi, então, que aquilo que tinha para mim mesma apenas uma dimensão psicológica, era efetivamente um problema filosófico. A atração foi enorme e a consciência das dificuldades de Espinosa também era enorme. Nas primeiras vezes em que li o "Tratado da Reforma", a 'Ética", eram textos incompreensíveis que me deixavam completamente aturdida. Achava que jamais teria condições para entendê-los. No intervalo, fiz um curso de Pós-Graduação com o Lebrun sobre Hegel e parecia uma epifania: finalmente a compreensão da necessidade e inteligibilidade da história! Cheguei a pensar em escrever um trabalho de mestrado sobre Hegel, mas a leitura da "Fenomenologia do Espírito" produziu o mesmo efeito que a da "Ética": incompreensão total. Li Hyppolite e aconteceu algo curioso, pois o que mais me interessou foi a figura da consciência infeliz. Percebi, então, que era sempre a mesma questão, que iria ler Hegel pelos mesmos motivos que desejava ler Espinosa e voltei a Espinosa. Porque achei (não sei hoje se diria o mesmo), mas achei que Espinosa, de alguma maneira, apontava uma relação entre o finito e infinito e a liberdade sem passar pelo grilhão de culpa. Se você quiser, foi o cristianismo de Hegel que me afastou dele, porque nós éramos " $\mathrm{i}$ guais". E foi a violência de Espinosa, com relação a todas as representações que marcaram meus pensamentos e minhas ações, que me fez ir a ele. Independentemente da questão do tempo ser a grande questão. Acho que essa questão do tempo aparece na tese de livre-docência sobre Espinosa, mas, curiosamente, não através de Hegel, mas através de Lefort. Por que Hegel e não Espinosa, você me pergunta. Porque Hegel me conservaria dentro do universo cristão e Espinosa era a minha possibilidade de sair desse universo, de encontrar outra maneira de pensar. 
Ent. - A minha questão volta um pouco, Marilena. Quando eu lhe colocava a questão de um uso moderno da burocracia como uma face desse instante ideológico, e tentava ver que isto, no nosso pequeno universo de Departamento de Filosofia espalhados por aí, você dizia pouco antes, desta filosofia como movimento que se encharca na história e na história do aí e agora: como você vê, ou como você poderia nos ajudar a pensar - usando esta maior ou menor exemplaridade que nós possamos ter, como os professores que você citava do Roosevelt - uma utilização desses materiais que, enfrentando a ira do burocrata contra a heresia do afastamento da filosofia entre aspas, utiliza esses materiais do cotidiano e da realidade imediata envolvente, que passam pelo teatro, que passam pela literatura, que passam pela música, que passam pela poesia, e assim sucessivamente. E isto, sobretudo, recuperando um pouco esta noção que me parece cada vez mais urgente ou conveniente - da exemplaridade possível - depois de 18 anos de desorientação. Porque, a meu ver, esse uso de discursos diversos me parece se tornar mais eficiente, ou mais ainda, uma alternativa, uma terceira alternativa entre o discurso exumado do "filosófico" puro, entre aspas, e um discurso muitas vezes gerador de perplexidades e incompreensões do "político" também puro, e por isso entre aspas.

Mar. - Vejo essa terceira alternativa como a contribuição ef etiva que cada um de nós pode dar tratando de música, de poesia, de cinema, de pedagogia, de história, da própria figura do intelectual, ou tratando desse fenômeno alarmante que é a tentativa de se opor à burocracia através do coração, através da exarcebação dos sentimentos. Penso que a contribuição que nós temos a dar, independentemente da alta ou baixa qualidade que ela possa ter, é a de um trabalho, de uma reflexão que por estar assentada (eu vou usar entre aspas a palavra seguinte) numa "tradição de filosofia", nos torna lúcidos e perspi- cazes para as armadilhas do cotidiano, para as armadilhas da Universidade, para as armadilhas das ideologias, para as armadilhas da política. Embora eu não faça de modo algum a apologia do intelectual pedagogo, aliás muito pelo contrário, faço a crítica do intelectual pedagogo, acho que nós temos uma chance de decifrar a dissimulação e a mistificação de tudo que aparece como ordem, racionalidade. Podemos, enquanto professores, enquanto divulgadores, enquanto publicistas, enquanto escritores realizar isto, talvez em condições mais sólidas do que outros que desejam fazer isto, mas cuja formação, feita durante esses 19 anos, encontrou dificuldades maiores do que aquelas que nós encontramos anteriormente. Quando você fala em exemplaridade, eu pensei exemplaridade um pouco na linha dos professores do curso secundário e dos professores universitários quando, usando os instrumentos que nossa formação nos deu, opondo o pensamento às resistências do cotidiano, de alguma maneira oferecemos ao outro possibilidade para fazer esse trabalho conosco, companheiros numa trajetória. Ao mesmo tempo eu acho que é, sem querer ter uma visão missionária desse tipo de trabalho, eu acho que é uma taref a política muito séria, essa de desmistificar a cada passo a cumplicidade dos discursos e das práticas que se oferecem como antagônicos uns aos outros. Acho que se a gente puder, a cada passo, mostrar que não são antagônicos, que são profundamente cúmplices, faces, verso e reverso do mesmo, eu acho que seja qual for o campo de reflexão em que nós estejamos trabalhando, a gente está exercendo aquilo mesmo que ela tem de mais corrosivo. Eu acho que o que há de mais corrosivo na filosofia é a possibilidade de desmontar a cumplicidade do mesmo, a aparência do diverso na qual você não tem diferenças, mas o mesmo diversificado, acho que nós somos capazes de fazer isso. 
Ent. - ...capazes de acolher o tratado da reforma do entendimento e o tratado teológico-político.

Mar. - E de mergulhar no Livro I da "Ética", trabalhar com a constituição da causa imanente e ir ao parágrafo 27 do capítulo 9. ${ }^{\circ}$ do "Tratado Político" perceber qual é a imagem que o dominante possui da plebe e que justifica a exclusão da plebe de todas as decisões. É o mesmo trabalho. Compreender a identificação da necessidade divina com a autoridade divina operada pela metafísica e compreender como e por que a causalidade imanente critica isso e introduz a liberdade, permite compreender porque a imaginação torna perfeitamente possível um discurso que legitime de maneira coerente a exclusão de alguns do campo da política. Eu acho que é com a mesma intensidade e com o mesmo rigor que a gente pode trabalhar com uma questão metafísica e com a outra, política. Então, eu não acho, como acha uma longa tradição de intérpretes de Espinosa, eu não acho que a obra política de Espinosa seja um apêndice de circunstância à "Ética", mas é constitutiva do pensamento dele. Como não acho que é coisa de circunstância Merleau-Ponty dedicar um estudo à pintura de Cézanne. Eu acho que, sem querer fazer da reflexão filosófica a captação do uso e do todo, a reflexão filosófica é a possibilidade de exercer o pensamento na diferença, e como professores, nós temos uma chance enorme de fazer isso. Por isso que eu sou tão contrária à divisão das tarefas do professor de filosofia. Por que é que alguém não pode dar um curso sobre a poesia de Fernando Pessoa, Carlos Drummond ou Baudelaire e um curso sobre o "Tratado TeológicoPolítico"? Por que alguém não pode, tendo meditado sobre os processos pelos quais e nos quais a liberdade é mistificada; compreender a Ação Integralista Brasileira? Acho que isso é possível, sem o ecletismo e sem que seja a opção de nossa vida. Acho que cada um de nós fez uma opção em filosofia, que há determinados problemas, certas experiências, alguns filósofos para cada um de nós constituem a pesquisa de nossa vida inteira. Há coisas que nos causam dor, cólera, felicidade, dúvida e prazer, e é com essas que a gente lida fundamentalmente, mas ao redor disso, acho que nós estamos preparados para lidar com o restante também, que é o que o burocrata não suporta.

Ent. - Aliás, Marilena, uma questão que diz respeito não bem à astúcia das idéias, mas à astúcia do poder travestido de burocrata e que remonta uma vez mais a essa divisão de tarefas. Como você veria a questão e como você veria a superação desta questão? De 64 para cá, uma literatura diferente se faz no Brasil. Conforme épocas e circunstâncias muito marcadas, pode-se pensar desde o Antonio Callado de Quarup e Bar Don Juan até, como limite superior desse primeiro momento, talvez o Ivan Angelo de $\boldsymbol{A}$ Festa. Mas de lá para cá uma literatura nova vem-se fazendo, incluindo especialmente o Roberto Drumond, o Renato Tapajós, o Renato Pompeu, mais recentemente o Paulo Francis (gostemos ou não), e que, de uma maneira compreensivelmente tateante, canhestra, muitas vezes desencontrada e até infeliz, pensa, discute, quer pensar, quer redescutir 64, 68 para cá. Trazida essa questão para o nosso meio como provocação, como desafio, como trilhas, como percursos, muitas vezes nós encontramos e temos encontrado dois tipos de obstáculos. Um, a diferença do próprio material ainda muito quente, mas outro novamente o olhar julgador do burocrata que assim como há pouco distinguia, tranchando (desculpe o galicismo), cortando a machado, Ética de um lado e Filosofia Política de outro, nos diz agora, com o dedo no nariz, que isso não é Filosofia... Então eu lhe perguntaria, resumindo: como você veria esta produção literária, que é uma produção crítica ao mesmo tempo, como questão política e como questão filosófica; e, num segundo momento, como você veria ou como você vê as nossas possibili- 
dades - agora eu falo também para a vice-presidente do SEAF - de enfrentar esse dedo em riste no nariz, que separa as águas boas, as limpas e as "sujas" do outro lado.

Mar. - Olha, no primeiro caso eu incluiria também, entre os que você mencionou, eu incluiria também o "Copo de Cólera" do Raduan Nassar, que é diferente de "Lavoura Arcaica". O "Copo de Cólera" vai mais na linha do tipo de literatura que você mencionava. Considero essa nova literatura, com todos os problemas que você colocou, fazendo um serviço absolutamente fundamental no Brasil, e que é o seguinte: nunca neste país se elabora, no calor da hora, a contramemória. Essa literatura está produzindo a contramemória, quer dizer, você tem a memória oficial celebrativa para 64 e 68 e normalmente seria preciso esperar (como esses que estão de dedo em riste no nosso nariz) pelo ano 2000 para desmanchar e desmantelar a celebração e refazer uma outra memória que desfizesse a oficial. Nossa literatura resolveu não esperar pelo ano 2000 .

Ent. - Marilena, injusta... e As Memórias do Cárcere?

Mar. - Não é injustiça. Mas é excepcional, porque você não tem um movimento literário, mas Graciliano sozinho fazendo isso.

Ent. - É massacrado pelo Jorge Amado...

Mar. - Claro. É ele sozinho fazendo isso. Tanto que ele é a exemplaridade justamente por causa da solidão, e o que a gente verifica agora, numa forma que nem sempre tem a envergadura e o cuidado do Graciliano, que está muito mais próxima do jornal do que daquilo que tradicionalmente nós consideramos "romance", mas de qualquer modo você tem algo coletivo, são muitos a fazer aquilo que, uma vez, Graciliano fez sozinho e massacrado. Essa desmontagem da memória oficial, pra usar a expressão da Walnice, no "calor da hora", me faz considerar que esse aspecto, hoje, na literatura, é fundamental. No caso da filosofia, acho que os "críticos" não estão conseguindo perceber (ou estão percebendo muito bem e estão com medo) que está ocorrendo um tratamento filosófico de assuntos e de experiências que o senso-comum universitário julga não serem "filosóficos". Em geral, os que dão dedo em riste contra o nosso nariz, dizendo que o assunto é quente e que o assunto não é filosófico, é porque não perceberam que ele está sendo filosoficamente tratado. Isso é o que eu acho mais triste: os que nos criticam, em nome da "Filosofia", por não estarmos fazendo filosofia. O que essas críticas mostram é que não se percebe todo o trabalho teórico da filosofia que está presente nas análises que estão sendo feitas. Então, aquele que está criticando imagina estar criticando em nome da filosofia, e provavelmente, está convencido disto. O que é lamentável é ele não perceber o lastro filosófico que está sustentando cada uma dessas análises e que cada palavra empregada tem toda uma história da filosofia atrás dela. Então há uma insensibilidade filosófica - eu prefiro a palavra insensibilidade à palavra ignorância -, há uma insensibilidade filosófica nessa crítica do dedo em riste, porque é uma crítica que é incapaz de perceber que, porque você não está trabalhando, invocando a cada segundo o conceito e a sua origem, mas você está trabalhando a partir dele para fazer a sua análise, como o indivíduo lê a sua análise e não tem sensibilidade pra perceber toda a filosofia que está por trás disso, toda a bagagem conceitual que lhe permitiu aquela análise, ele diz que não é filosofia.

Ent. - É a repetição entre nós do que acontece com a Walnice, do que aconteceu na França com o Macherey com as análises que ele fez do Jules Verne.

Mar. - Quer dizer, você está legitimado se você for um repetidor. Se o que um outro deu pra você pensar, o que ele criou e que dá a você meios para realizar a sua 
própria reflexão, não é percebido (e não é percebido porque se desconhece de onde o pensamento veio), como não se percebe o lastro do seu próprio pensamento (porque ele não está no rodapé), então simplesmente seu trabalho não é filosófico. Então, o crítico atesta a sua própria ignorância, atesta a sua própria fulgurante burrice ao não perceber que muitas vezes é o movimento do seu texto, não é nem o assunto nem o conceito, é o movimento do seu texto que é filosófico. Se não se percebe que o seu texto fez um movimento, que esse movimento é essencialmente consțitutivo do texto e que esse movimento é a filosofia do e no texto, pode-se pôr o dedo em riste, mas se põe o dedo em riste simplesmente porque não se entendeu o trabalho que você fez. É muito fácil, eu acho, as pessoas se arvorarem em críticos de trabalhos voltados para o nosso presente, é muito fácil porque as pessoas estão de alguma maneira habituadas a um tipo de trabalho no qual se considera a reflexão do escritor um elemento mínimo. Se ele é um bom compilador, se ele é um bom comentador, se ele é um bom repetidor e se ele é suficientemente astucioso para montar o texto, isso é considerado filosófico. Se ele, aos trancos e barrancos, pensa, já não é filosofia.

Ent. - Você veja que esta questão (estou insistindo um pouco nela) vem até agora assumindo um certo etnocentrismo professoral da nossa perspectiva, mas é que nós estamos saindo de encontros recentes com nossos alunos em que, discutindo e pensando atividades acadêmicas como jornadas de filosofia e semanas de filosofia, os alunos repetem com insistência sintomática um pedido que denuncia um vazio nas nossas atividades e nos nossos trabalhos: e a filosofia no Brasil? E um curso sobre filosofia no Brasil? O Paim não é filosofia no Brasil? É só Cruz Costa? E muitas vezes nós nos vemos na situação delicada, incômoda, ou de assumir ou talvez revelar até as últimas conseqüências divisões e grupos conhecidos. Então, mui- tas vezes vamos nós nos vermos nessa situação incômoda de expor, revelar os bastidores. Ou então, daí eu me pergunto da conveniência de levar adiante essa discussão face a essa elaboração simultânea do que você chamou bem da constituição da contramemória, no calor da hora, se não seria por aí também que nós poderíamos retomar ou re-retomar o nosso diálogo interrompido ou dificultado até recentemente.

Mar. - Acho que sim, porque sou muito a favor de que a distância geográfica não seja transformada em hierarquia de competência. Penso que discussões como esta, justamente porque ela vem de todas as partes, não só do Estado de São Paulo, mas de todas as partes do Brasil, dos centros de filosofia, sobre as mesmas questões, acho que essa simultaneidade e semelhança das perguntas que os estudantes nos fazem, ao mesmo tempo que revela, como você disse, um vazio em nosso trabalho, revela um ponto que é comum a todos, porque está sendo solicitado por todos. Ora, acho que não há coisa mais produtiva pra estabelecer diálogo, diferenças e proximidade do que partir de um solo comum que tenha sido solicitado como algo que merece reflexão. Temos aí um assunto, um tema, uma questão que está sendo sistematicamente solicitada pelos estudantes. Se pudermos tomar isso, não só vamos ef etivamente trabalhar com algo que é sentido pelos estudantes como importante, como também vamos retomar todo um passado de feitura de filosofia no Brasil e possivelmente, por esse caminho, diferenças entre nós vão ficar mais claras, proximidades entre nós vão ficar mais claras. E como a temática é uma temática que seria igualmente tratada por nós todos, o risco de distinções hierárquicas entre nós se aboliria. Teríamos uma reflexão sobre filosofia que é comum a nós todos, porque as nossas diferenças e nossas proximidades se explicitam. De modo que, politicamente, também acho isso importante, e não só filosoficamente importan- 
te. Pedagogicamente também é importante porque veio de uma solicitação dos estudantes e politicamente é importante para termos claro quem somos uns para os outros.

Ent. - Naquela entrevista que o Lefort deu pra Isto É, ele diz, referindo-se a você que você rompeu com o marxismo ortodoxo. Eu gostaria que você explicitasse esse viés do seu pensamento, essa ruptura com o marxismo ortodoxo e se MerleauPonty e Espinosa têm a ver com isso.

Mar. - Têm tudo. Bom, a minha resposta vai ser longa, não faz mal? Quando eu tinha por volta dos meus 15 anos, eu fazia, como todo adolescente, leituras mais disparatadas. Lia Madame Delly com o coração aos saltos e lia trechos traduzidos para o espanhol da "Interpretação dos Sonhos". De Madame Delly ao Freud, sem solução de continuidade. Uma das preocupações que eu tinha, vinda da minha formação cristã, era o problema da desigualdade social e da injustiça. Eu tinha discussões homéricas não só com colegas minhas, mas com pessoas de minha família. E sistematicamente eu perdia as discussões porque o argumento fundamental que era levantado contra tudo que eu dissesse era que a natureza humana é assim mesmo e que se a injustiça e a desigualdade fazem parte da natureza humana, é só por um gesto de loucura que você quer suprimir essas coisas. Em momentos de discussões desse tipo, eu chegava a um ponto de exasperação tão grande que começava a gritar. Então, por volta dos meus 15 anos, me caiu nas mãos um livro e quando terminei de ler esse livrinho eu me disse: Pronto. Acabou. Quero ver alguém discutir comigo. Vou provar por $\mathrm{A}$ + B que a injustiça e a desigualdade não vêm da natureza humana e que é possível mudar isso. E que é possível não porque eu sou uma revoltada louca, mas porque é cientificamente possível. Caíra nas minhas mãos o "Socialismo Científico" de Engels. Tive o sentimento de ter sido salva, resgatada, me tornando uma verda- deira fortaleza. Aí eu puxava a discussão e quando a discussão chegava no seu clímax, que era o momento em que normalmente ela se interrompia, com o argumento da natureza humana, eu vinha com Engels a todo vapor. Vinha a história e vinha a ciência. Esse livrinho foi, então, um elemento muito poderoso pra mim, na medida em que, diante de pensamentos contra-revolucionários, pensamentos conservadores, pensamentos reacionários, ele me dava uma arma imbatível, que é a arma da demonstração científica da igualdade, da liberdade. Daí, passei ao "Manifesto", evidentemente, e depois li, de maneira muito fragmentada, textos marxistas, algumas coisas de Lenin, de Plekanov, evidentemente. Depois, já iniciando o curso de filosofia, e de uma maneira mais sistemática, alguns textos de Marx. O que era curioso é que a força que tinham tido sobre mim o livrinho de Engels e o "Manifesto", força argumentativa, política, os outros textos marxistas não tinham. Eu não me sentia politicamente satisfeita, persuasivamente forte e intelectualmente convencida com o restante dos textos marxistas que eu lia. Isso é uma coisa que eu não consigo saber por que, mas de alguma maneira determinou o fato de eu não ter pertencido a nenhuma das organizações que estavam disponíveis. Embora, por exemplo, um texto como o de Trotsky, "A moral deles e a nossa" tenha sido também fulgurante para mim. Comecei a ler "O Capital". E "O Capital" aparecia pra mim tão diferente do marxismo, tão incompreensivelmente diferente do marxismo, que eu nunca tive coragem de verbalizar isso, porque eu sempre achei que eu não era capaz de entender Marx. Eu achava que era porque eu não entendia Marx que eu não conseguia perceber como o restante da literatura marxista nascia de "O Capital". Li, então, "Humanismo e Terror". E ao ler "Humanismo e Terror", de alguma maneira o que se fortificou em mim foi alguma coisa chamada "Marxismo", mas que era completamente indefinido, era muito 
mais o sentimento de que durante a guerra fria você não pode ser macartista. Era um "marxismo" que se reduzia mais a isso. Ao mesmo tempo, eu sempre me considerei de esquerda, a leitura da "Ideologia Alemã' foi importantíssima e a certeza de que a história passa pela luta de classe era inegável. $\mathrm{O}$ meu problema maior era o fato de que não só no plano da pouca literatura marxista que eu havia lido, mas no meu contato efetivo com os marxistas, predominaram primeiro os stalinistas e depois os trotskistas e, de alguma maneira (acho que por causa da filosofia), a segurança dessas pessoas com relação a tudo que para mim era interrogação, sempre me deixou muito assustada. Então, não é que eu tenha rompido com o marxismo ortodoxo, mas sim que eu nunca consegui entrar no marxismo ortodoxo. Sempre houve qualquer coisa que bloqueou a adesão. Fiz esse relato autobiográfico porque justamente aquilo que no texto de Engels tinha sido tão fundamental para mim na adolescência, a argumentação sem nenhuma fissura, a argumentação completa e a demonstração de necessidade do caminho histórico, aquilo que me impediu de fazer a "Marcha com Deus pela família e pela propriedade"', em 64, no entanto, foi essa mesma segurança, essa mesma história demonstrativa, sem possível e sem futuro, inteiramente feita e já pensada, foi isso que me afastou da ortodoxia. É alguma coisa muito curiosa, porque foi o socialismo científico de Engels que me permitiu não ser uma pessoa de direita e, no entanto, foram os meus contatos com a literatura e com pessoas stalinistas e posteriormente certas linhas trotskistas excessivamente autoritárias que também me impediram de cair na ortodoxia. Não atribuo isso tanto a Merleau-Ponty, porque o trabalho mais sistemático que passei a fazer com as "Aventuras da Dialética" é muito recente. O Merleau-Ponty que eu conheci era o Merleau-Ponty que certamente não teria me afastado da ortodoxia, porque era o Merleau-Ponty de "Humanismo e Terror'”. Eu diria que provavelmente o meu marxismo não é ortodoxo, talvez porque eu desconheça profundamente o marxismo. Não é porque eu conheça profundamente o marxismo e tenha feito a crítica dele e me afastado que eu não sou uma marxista ortodoxa, mas talvez porque o marxismo ortodoxo me assustou tanto que eu não pude me aproximar muito do próprio marxismo. Quer dizer, acho que o estudo que venho fazendo do marxismo é uma coisa muito recente. Nos últimos 4 ou 5 anos é que eu tenho trabalhado de uma maneira sistemática com isso. Num momento em que, de alguma maneira, se torna menos penoso você fazer esse estudo sistemático porque, dada a situação política dos lugares onde as revoluções foram feitas, você pode penetrar na obra de Marx sem risco de fazer dela uma religião. Quer dizer, há entre a obra de Marx e os acontecimentos revolucionários um contraponto histórico de tamanha envergadura que você pode ler Marx percebendo Marx pensando, os vários caminhos que ele segue, as linhas possíveis que há no pensamento dele, a nãolinearidade. Acho que poder me aproximar de uma maneira mais sistemática da obra de Marx num momento em que é possível não tomá-lo como religião é, na minha biografia, uma coisa muito importante porque se eu tivesse me deixado absorver por essa religião secularizada que é o marxismo ortodoxo, estaria salva do meu catolicismo, que foi o que eu procurei tanto. E não foi possível. Talvez, no fundo, de uma maneira muito vaga, eu sentisse que estaria trocando um autoritarismo por outro e certezas por outras. $\mathrm{O}$ fato de fazer um curso de filosofia, mesmo sem que eu estivesse produzindo alguma coisa, estar fazendo filosofia de um modo muito livre me imunizou contra a ortodoxia. Acho que não é por acaso que uma das críticas mais freqüentes que me fazem é a de eu não ter uma "posição definida". Acho que tenho uma posição definida: a minha posição é não ter certezas definidas que me garantem "posições definidas". E nesse ponto, o contato com 
Claude Lefort, tanto com a obra dele como com a pessoa dele, foi muito importante para mim. Não só porque é uma fonte de aprendizagem, mas sobretudo porque se trata de alguém que viveu com uma intensidade desconhecida para mim (não é que não tenha havido no Brasil, mas foi uma experiência que eu, no Brasil, não tive) o horror do autoritarismo de esquerda. E é o fato também de que é alguém que lida com o pensamento de Marx sem nenhuma intenção de desqualificar Marx. Muito pelo contrário, procura apanhar em Marx as descobertas, os instantes fundadores do marxismo, seus limites, impasses e riscos. Eu diria que a presença de Lefort foi uma coisa muito importante na minha trajetória. Que é essa trajetória curiosa, porque de alguma maneira a salvação trazida pelo Engels teria me levado direto da Igreja para o Estado, porque era uma salvação religiosa. Engels me trazia algo que só a Bíblia dava aos outros. De alguma maneira, isso não aconteceu.

Ent. - E tem outra coisa: eu já ouvi você ser tachada de anarquista. O que você teria a dizer sobre isso?

Mar. - Olha, na verdade, acho que há uma dose de autoritarismo muito grande também no anarquismo. O que não significa que eu não sinta um verdadeiro fascínio pelos anarquistas. Quer dizer, por exemplo, a análise que Bakunin faz da Comuna, eu gosto mais da análise dele que da do Engels e sinto enorme respeito e admiração pelos anarquistas e anarcosindicalistas do início do século, no Brasil. Mas não me considero anarquista, se por anarquismo a gente entender uma posição política que tem uma história própria. Agora, se você considerar o anarquismo como a liberdade de não ter posições definidas a partir de certezas definidas sobre a história, então eu aceito ser chamada de anarquista, porque eu tenho dúvidas, perplexidades, suspeitas, de vez em quando acho que descubro algumas coisas, que entendo algumas coisas, mas, muito rapidamente, eu me dou conta do quanto é parcial a descoberta que eu fiz, e quanto mais haveria a fazer. Acho que é muito importante a gente se responsabilizar pelos próprios escritos e pelas próprias falas porque dá a você o direito de se desfazer deles, o direito de dizer: "Pensei isto; pensei, expus e me responsabilizei pela minha fala e pela minha escrita, mas não penso mais isto por tais e tais motivos." Há um aforismo do Nietzche que eu acho perfeito: "Nós não nos deixaríamos queimar pelas nossas opiniões. Não estamos tão seguros delas. Mas talvez nós nos deixássemos queimar pelo direito de podermos ter opiniões e de podermos mudálas." Isso sim. Eu acho que a gente se deixa queimar pelo direito de mudar de opinião.

Ent. - Uma coisa que me chama muito a atenção nisso que você diz, vindo também de observação do pensamento de esquerda no Brasil, essa confluência cada vez mais inquietante do pensamento católico com as ortodoxias. Eu me espanto quando você fala do Engels, essa capacidade de expor verdades claras e distintas de uma maneira literariamente cativante. E me espanto porque esta clareza é própria dos catecismos do século passado, porque o catecismo dos Industriais de SaintSimon é uma beleza, quer dizer, é um convencimento perfeito, é uma lógica extremamente simples, você tem o catecismo positivista. Então, no caso do socialismo utópico ao socialismo científico, ou do Manifesto, você tem essa ingenuidade de se confessar catecismo. No entanto, esses catecismos, hoje, se transformaram em tratados de filosofia materialista, ou eles se transformaram em ensaios sobre a dialética da história, ou crítica de qualquer coisa e o que é interessante, no caso do catolicismo, a partir do pensamento marxista, é justamente esse fascínio por Engels, quer dizer, você conversa com um intelectual, ou militante católico progressista, você fala do Capital, ele pula e diz: não, isso é muito teórico, isso é uma coisa que não me diz respeito, mas no momento se- 
guinte ele provou a necessidade de $\mathrm{x}, \mathrm{y}$ e $\mathrm{z}$, tais políticos a partir do Engels da Origem da Família, da propriedade privada. Quer dizer, essa corrida ao Engels...

Mar. - Entre os estudantes também.

Ent. - Sobretudo. Então, lembra? Uma das questões que você abordou no seu trabalho, no seu curso, é a questão da repressão, que me atraiu profundamente, da repressão interna, já no tempo de Marx, já no tempo de Engels. Quando se lembra a história da crítica do programa de Gotha um texto que aparece contra o pensamento estabelecido do socialismo oficial, esse texto foi engavetado durante 50 anos mais ou menos, e não me lembro a data exata, faz bastante tempo, e quando ele foi publicado, foi publicado cortado, ele foi publicado censurado. Ora, são dois perigos porque o texto foi censurado, o que lhe dá um charme hoje, um charme de inegável verdade. $O$ que é extremamente complicado, porque as coisas em relação ao Estado são complicadas, são extremamente problemáticas pra nós que vivemos numa experiência pós-totalitária ou totalitária. Esse charme do qual compartilha, por exemplo, o Gramsci, então as separações escolásticas, especiosas do Gramsci, o Gramsci autoritário, o Gramsci da juventude etc., na realidade pra salvar a ortodoxia, a boa ortodoxia. Quer dizer, no fundo você se nega a enfrentar isso, você aponta que é a falibilidade do pensamento. Quer dizer, você se nega a enfrentar o erro. Você escapa, procura sempre certezas. Quer dizer, e a outra prova que me aparece extremamente danosa é a prova da prática. Eu me lembro, por exemplo, você citou Nietzche, eu me lembro de um aforisma magistral onde ele diz: dar o sangue pelo que se acredita, o que prova isso? A todo instante, nós que fazemos filosofia aqui no Brasil, nós nos enfrentamos com esse problema que vem não apenas da ortodoxia estalinista ou da ortodoxia trotskista ou da maoísta ou de toda a gama das ortodoxias, mas também do catolicismo e também da razão de Estado, quer dizer, a inu- tilidade da filosofia. O que fez o Bento, me parece, magnificamente responder: precisamos rir da filosofia mesmo, porque a filosofia é inútil, ela é inútil mesmo, não serve para nada. Também como dizer: não serve para nada....

Mar. - Não prova nada.

Ent. - Então, realmente, eu acho isso um dos veículos mais fundamentais de sua pesquisa, do seu trabalho, quer dizer, essa tentativa de mostrar, olha gente, espera lá, a verdade não reside, por isso eu lhe perguntei sobre o tempo, porque de uma certa maneira, Santo Agostinho pôde dizer: bom, a prova do tempo é que ele passa, o tempo flui, desaparece, certos estão, fazendo a passagem, os nossos militantes, quer dizer, o tempo corre, é preciso ganhar do tempo. Então, como nós precisamos ganhar do tempo, ganhando espaço e tendo a estabilidade, e tendo o eterno e tendo a ortodoxia. Quer dizer, nós temos a ciência pronta, então trata-se de aplicála o mais depressa possível.

Ent. - Nós temos o voto útil...

Ent. - Claro, nós temos a utilidade. Então, puxa, por que fazer filosofia hoje no Brasil? Realmente, se sobrar um mínimo de possibilidade de perguntar, já teria assim um ganho enorme para o gênero humano, para a classe operária, para os pobres e oprimidos, para todo o mundo...

Ent. - Para o Ser...

Mar. - É, se a gente puder ter o direito de indagar, sem a obrigação de responder.

Ent. - Várias vezes você é cobrada: você não pensa dialeticamente.

Mar. - Que eu não penso dileticamente, que faço críticas mas não dou as alternativas, que oscilo entre uma posição e outra e quem me lê não pode tomar um parâmetro para agir etc. Fiquei muito aliviada quando ouvi essas críticas. "Você tem tantas posições simultâneas que a gente termina de ler e vai pra prática e não sabe em qual das posições ficar" - isso é uma 
coisa que me dizem sempre, como se eu tivesse escrito para dar receitas de ação. Fiquei assustada, com medo de ser lida por pessoas que esperam da leitura de um texto a fórmula para agir, quando meus textos são contra isso. Ao mesmo tempo tive a satisfação de perceber, pelas críticas, que não dá para fazer isso. Há um outro tipo de crítica, que não é exatamente crítica, mas já é agressão: “É tudo impreciso, é indeciso, não tem contorno." Não é bem isso. Há perplexidades que coloco no papel, só isso.

Ent. - No fundo, é interessante porque o autoritarismo da esquerda é compartilhado pelo autoritarismo da direita e os dois são manifestações opostas, mas do mesmo. Proclama-se dialético, mas no fundo o que se procura é a identidade: A igual a A. O que sempre se procura é o pensamento parado.

Ent. - Retomando aquela revisão do seu itinerário no e através do marxismo, como você vê a questão da crítica da análise da superestrutura, da cultura, especialmente no que diz respeito à literatura? Onde, fora os trabalhos iniciais do próprio Marx e mais tarde de Lenin e alguns de Plekanov, se teve um momento de certa forma privilegiado na Itália com Gramsci e Della Volpe, um pouco na França (inclusive direcionado, localizado na literatura) e, entre nós, no Brasil, praticamente nada.

Mar. - Olha, eu tenho uma hipótese, mas não sei qual o valor dela. Partindo da discussão de Korsch sobre a pecha de "marxismo ocidental" que o marxismo russo ou bolchevismo lançara contra os trabalhos que os intelectuais marxistas estavam fazendo no restante da Europa, eu penso que uma das razões pelas quais a questão cultural foi deixada de lado se deve ao poder avassalador do estalinismo. No seguinte sentido: se você leva em conta as vias de reflexão sobre a cultura, se você toma, na Itália, um sujeito como o Gramsci, ou se você toma, bem mais tar- de, na França, a linha que sai do Althusser, alguém como o Macherrey, ou se você toma a linha frankfurtiana, você nota que o interesse pela questão da cultura vem ligado muito a uma tentativa de repensar a própria idéia de partido. Eu veria a coisa sob o seguinte ângulo: no Gramsci, é nítida a discussão a respeito de o partido ser, como um todo, o encarregado de uma revolução cultural; acho que não é por acaso que o tema da hegemonia seja um tema tão importante no Gramsci, pois está vinculado a uma tentativa de repensar a ação do partido. Do lado dos frankfurtianos, tenho a impressão de que a discussão é profundamente ligada, por um lado, à crítica da social-democracia e, por outro lado, ao problema da emergência do totalitarismo, à questão de saber o que, na cultura alemã, suscita a adesão às linhas totalitárias. No caso da França, a discussão esteve muito ligada ao fato de ter havido uma revolução cultural na China. São instantes nos quais a questão partidária, a questão da adesão das massas a formas totalitárias, o fato de ter havido revolução cultural levam a perguntas em torno do problema da cultura. No caso do Brasil, acho que há dois níveis de problemas, no tocante à cultura. Por um lado, a perspectiva profundamente estalinista dos intelectuais marxistas fez com que fosse muito difícil discutir a questão da cultura porque seriam obrigados a ter como referencial única e exclusivamente o realismo soviético. Acho que os problemas que atualmente eles enfrentam com relação à necessidade de repensar a questão cultural, e a ida ao Gramsci estão muito ligados ao fato de que foram submetidos a uma verdadeira couraça para pensar a questão da cultura apenas sob a perspectiva do realismo soviético que, por definição, torna impossível discutir o problema da cultura. Por outro lado, acho que o medo da análise da cultura, via Luckács foi muito grande. Ou seja, o fato de que a análise luckacsiana não tenha aparecido como um conjunto de reflexões que Luckács faz sobre a cultura européia e com 
momentos datados muito precisos, mas como um receituário, de tal modo que em vez de o problema da cultura ser para nós um problema, na verdade, a cultura já estava explicada através do Luckács e o que você tinha que fazer era adaptar a realidade brasileira à explicação luckacsiana. Havia então uma pobreza muito grande na produção marxista a esse respeito. Acho que dois outros elementos também foram muito poderosos para limitar as reflexões de esquerda no Brasil em torno do problema da cultura: o primeiro foi a prevalência de uma ideologia nacionalista. $\mathrm{O}$ que implica no caso da questão da cultura a ideologia nacionalista? Ela implica na pressuposição de que a produção cultural dotada de sentido, válida, historicamente conseqüente, é a produção nacionalista cujas características já estão dadas por definição. Então você não tem que estudar o problema. Você tem simplesmente que mostrar quem é nacionalista e, por ser nacionalista, que é progressista e deve ser considerado cânone em matéria de produção cultural. O outro elemento que eu acho ideologicamente muito poderoso é o fato de que (e é uma coisa que você vê reaparecer em vários momentos, por exemplo nesse momento, na discussão dos movimentos feministas, a interdição, por parte dos marxistas ortodoxos, da discussão do problema da sexualidade das mulheres, porque o problema das operárias, o problema do trabalho e o das mulheres pobres é o problema da fome) a questão cultural é tomada como um luxo num país subdesenvolvido, porque a cultura é considerada uma coisa de elite e os problemas mais urgentes são os problemas da saúde, da moradia, da fome, enfim, os problemas da sobrevivência. O economicismo, portanto, tornava irrelevante a discussão em torno da cultura, como se a cultura não estivesse internamente articulada às condições reais da existência. Ela é efetivamente tomada como uma espécie de sobremesa. E você vai tratar da sobremesa depois que você serviu a mesa. Acho que isso teve efeitos autoritários muito poderosos, como por exemplo, todo tratamento a que foi submetida a cultura popular no final dos anos 50 e no início dos anos 60, em que o pressuposto era o de que a cultura popular, por ser do povo, é boa, é revolucionária, ela que está na corrente da história, mas porque o povo tem falsa consciência, a verdadeira cultura do povo é aquela que os intelectuais de vanguarda vão oferecer ao povo. A cultura popular acaba virando doação de cultura ao próprio povo pelos intelectuais. Então, eu veria o assunto da cultura por esses dois ângulos: quer dizer, o peso da figura de Luckács como um modelo que já definiu a questão cultural e você passa a tratar a cultura brasileira pura e simplesmente a partir desse modelo, ou, na outra vertente, que eu chamaria de vertente miserabilista, na qual a questão da cultura merece ser tratada exclusivamente depois que a revolução for feita e a mesa estiver servida. No caso dos intelectuais, acho que predomina muito o medo de cair no chamado "marxismo ocidental". Na medida em que o termo "marxismo ocidental"' é forjado no momento em que a política bolchevique está sendo questionada e com ela a cultura bolchevique, o "marxismo ocidental" é apresentado como filosofia dos intelectuais do Ocidente que não estão às voltas com os problemas reais de uma revolução. Com isto se generaliza a idéia de que qualquer discussão da cultura e qualquer discussão do modelo bolchevique é uma atitude contra-revolucionária. Então, há um grande medo de tratar do problema da cultura e ser tachado de contra-revolucionário. Por outro lado, na linha de uma hipótese como a do Perry Anderson, da qual tenho sérias desconfianças (se você se lembra, a hipótese do Perry Anderson é de que o marxismo ocidental se desenvolve num momento de refluxo proletário), considera-se que, quando se está fazendo revolução o tema da cultura não é um tema que interessa e que esse tema surge no momento do refluxo e, sobretudo, como uma discussão feita privilegiadamente por filósofos de origem 
pequeno-burguesa. Ha todo um esforçc para colorir a discussão cultural ou como sendo contra-revolucionária ou como sendo uma discussão desprovida de valor prático imediato, própria dos intelectuais pequeno-burgueses. Calculo que no Brasil todas essas coisas se mesclaram, ao lado de uma outra coisa que é complicada, mas que merece um pouco de atenção, isto é, o fato de que os marxistas brasileiros tinham uma informação paupérrima a respeito dos trabalhos do próprio Marx e mesmo do Lenin, do Trotsky, da Rosa. Há pouco tempo, o Weffort fez um balanço do que os marxistas brasileiros liam até o início dos anos 50. Eles liam o "Manifesto", o "Socialismo Científico", "Que Fazer?", “Estado e Revolução”, e praticamente só. Com exceção dos socialistas, como um Mário Pedrosa cuja cultura marxista era imensa. Então, com esse tipo de material e com um economicismo violento na perspectiva de pensamento, a questão da cultura se tornou realmente irrelevante. Sob esse especto, o surgimento de Luckács no Brasil foi um avanço imenso. Mas, bem ou mal, sempre prevalece a idéia de que o problema cultural é um problema de elite. E sendo um problema de elite, é aquele que menos interessa ao revolucionário. $\mathrm{O}$ que é gravíssimo, penso eu.

Ent. - Marilena, eu gostaria de deslocar a mesma questão para uma outra perspectiva, que é aquilo que se chamou a teoria da dependência. $E$ pensando no chamado boom da literatura latino-americana de 15, 20 anos para cá, desde Asturias até Vargas Llosa, mas passando por todo mundo da literatura que inclui entre nós o próprio Guimarães Rosa. Na realidade, visto de uma perspectiva de 20 anos, esse boom da literatura, que se propõe inicialmente fazer ou falar especificamente latino-americano, acabou fazendo o jogo do colonizador, na medida em que revivificou o folclore que o colonizador impunha: ora, nós existimos, nós somos diversos e ao mesmo tempo nós somos folclóri- cos. Aí retomo a interrupção que eu lhe fazia. Acho que está estritamente ligado a uma informação deficiente, do marxismo latino-americano, unilateral, limitada e muito enviezada por Luckács.

Mar. - Eu concordo muito.

Ent. - Tirou a institucionalização do folclore, do colonizador. Somos realmente bananas republics, estetizadas, mas bananas republics.

Mar. - E uma coisa fantástica que, a partir de um determinado momento, a latino-americanidade é o substituto continental para o nacionalismo.

Ent. - É o nacionalismo de quintal, de grande quintal, mas nacionalismo de quintal. Em vez de pequenos quintais, um quintal unificado que é, inclusive, mais fácil de vigiar e policiar.

Mar. - Ao mesmo tempo, acho que há um dado importante (que normalmente as pessoas não gostam muito que apareça), isto é, um grau profundo de ressentimento em toda essa produção. Está implícita nela, mais ou menos, a seguinte idéia: nós não existimos como potências econômicas, nós existimos, infelizmente, como dependentes da metrópole, mas vejam de que autenticidade nós somos capazes. Então, na verdade, você tem a incorporação do ponto de vista do colonizador, só que virada contra ele sob a forma do: "olha de que literatura nós somos capazes", "olha que música, que ritmo", etc.

Ent. - Inclusive com um componente de heroicidade trágica que é esteticamente linda...

Mar. - Essa mescla do elemento épico e do elemento trágico, do elemento messiânico como uma compensação, realmente uma compensação, e ao mesmo tempo como uma falsificação da produção cultural, porque você acaba falsificando a cultura efetivamente produzida, com todos os problemas que ela tem.

Ent. - Daí, no momento em que temos ainda pouca teoria sobre o momento que 
estamos vivendo, a importância do trabalho simultâneo sobre esse discurso que está sendo produzido, do contradiscurso, da contramemória.

Mar. - Eu acho fundamental, fundamental porque você desmistifica o discurso épico ou trágico no momento mesmo em que ele poderia ser forjado como uma resposta à memória oficial. Quer dizer, você tem uma memória oficial e depois você teria uma tentativa de resgatar os derrotados pela transformação deles em heróis épico-trágicos, e eu acho que o grande mérito dessa literatura que está aí é que ela desmistifica essas duas possibilidades. Ela desmistifica a memória oficial e desmistifica a tentativa de transformar isso numa imensa saga épica.

Ent. - Para mim, é com certa apreensão talvez até paranóica, que tenho trabalhado nessa linha, sem contudo retomar o tipo de trabalho do Cruz Costa, que tem outra linha. Sem entrar, naquela coisa tipo Paim, é preciso trabalhar sobre os últimos 20 anos do Brasil, não deixando passar mais 20 anos para voltar, e ao mesmo tempo muito preocupado - pode parecer discurso de lamúria - com a incompreensão ou resistência a um tipo de proposta como esta dentro da nossa Universidade, da Universidade brasileira, a atual.

Mar. - E também, uma incompreensão que está ligada (e isso é muito luckacsiano) à idéia de que a grande literatura é aquela que acompanha o movimento do capital. Então, nos pontos onde o capital realiza o seu apogeu, lá você tem a grande literatura. É fantástico porque você passa a ter a visão que a classe dominante tem de si própria.

Ent. - Por que Júlio Verne, por exemplo, é grande literatura, embora seja pequeno gênero? Porque ele expressa claramente o projeto ideológico da burguesia triunfante, otimista.

Ent. - Bom, Marilena, talvez como uma última questão, a gente gỏstaria que você dissesse como voce vê o panorama cultural, intelectual, hoje, no Brasil.

Mar. - Vejo algumas coisas novas despontando e a gente discutiu várias dessas inovações, aparecendo, pelo menos no nosso campo. Vejo no trabalho dos historiadores muita modificação, vejo na perspectiva dos antropólogos coisas muito interessantes, uma tentativa de ser etnógrafo da nossa própria sociedade. E, ao mesmo tempo, um fenômeno curioso que no meu entender está em via de desaparição, pelo menos do lado da "esquerda", porque é um discurso apropriado pelos intelectuais de direita. É o seguinte: logo depois da anistia, quando as pessoas começaram a voltar e começaram a se pronunciar, fiquei muito abalada, muito perturbada, porque tinha a sensação apavorante da repetição. Quer dizer, as pessoas voltavam e, especialmente, não só os políticos, mas os intelectuais, repetiam discursos velhos de 20 anos. Num primeiro momento eu pensei: vamos ter um renascimento do nacionalismo, um renascimento do populismo, vamos voltar à estaca zero. Mas agora percebi que não. Como esse é um discurso claramente apropriado pelo próprio Estado fica muito difícil, pelo menos para a esquerda, não digo para a oposição, mas pelo menos para a esquerda, manter esse discurso. Penso que as dificuldades, por exemplo, no interior do PC, não estão desligadas de problemas dessa ordem. De um discurso que é perfeitamente o discurso da ditadura e que se torna muito complicado de conservar. Vejo no panorama atual, no nível da produção intelectual mais geral, dois traços diferenciadores ou dois tipos de produção. Há uma, na linha da Universidade de Brasília, que não é só apenas claramente tecnocrática, não é apenas a dos intelectuais orgânicos da classe dominante, mas é uma linha que se pretende modernizadora, portadora de Modernidade. Isso é novo porque normalmente, no Brasil, a classe dominante sempre fez o discurso da conservação e não o discurso da moderni- 
zação. Com raras exceções, como Simonsen, nos anos 30, propondo o taylorismo e depois o fordismo. Mas é excepcional porque a classe dominante brasileira é conservadora. Agora surge a face progressista, com um discurso da modernização, de uma modernização que é científica. Acho que é a primeira vez que, com muita nitidez, os intelectuais de direita se diferenciam de um Tristão de Atayde por exemplo, como se diferenciam de um Miguel Reale. Não é nem a ideologia da Comunidade Universal, nem é a ideologia jurídica, a respeito da política e a respeito do próprio conhecimento. Não é o humanismo jurídico de um Reale, não é o humanisno católico de um Tristão de Atayde, não tem sequer a pretensão de ser um discurso humanista. Tem a pretensão de ser um discurso da ciência na sua forma moderna. Acho que todas as reformas que estão sendo propostas no plano da Universidade estão ligadas a essa ideologia da modernidade científica. No pólo oposto, vejo uma outra linha de produção intelectual prof undamente interessada em três questões principais. Primeiro, de apresentar alternativa no plano da saúde, no plano da ecologia, no plano da habitação, enfim, no plano das condições gerais de vida, um conjunto de pesquisas, de projetos, e de propostas de trabalho teórico com aplicação a longo e a médio prazo, visando não o desenvolvimento da nação, mas a melhoria das condições de vida das classes dominadas. Acho que isso é novo porque normalmente o que se tinha eram propostas de um desenvolvimento nacional que traria consigo a melhoria das condições de vida. Agora não, é um discurso claramente destinado às questões sociais. Segundo, uma produção muito interessada nisso que se discutia há pouco, de não tentar desfazer a ideologia dominante depois que ela cumpriu o seu ciclo, cumpriu a sua tarefa e aí se tornou objeto histórico de investigação, mas de fazer um trabalho para solapar a cada passo a construção desse discurso da modernidade científica. Vejo isso na literatura, na filosofia, nas ciências sociais, vejo isso também até nas chamadas ciências exatas. Terceiro (e isso eu acho o mais problemático), a ênfase que está assumindo na intelligentsia de esquerda a questão pedagógica. De alguma maneira, pelas visitas que tenho feito por todos os Estados do Brasil, o papel assumido pelas questões pedagógicas e a discussão em torno da educação como um elemento de libertação me parece uma coisa alarmante, pelo seguinte: vejo um risco muito possível de fazer da questão pedagógica a panacéia para a onipotência política, de fazer da questão pedagógica o substituto da ação política. Quero deixar claro o que estou dizendo. Não desvinculo (seria a última pessoa a fazer tal desvinculação) educação e política. Acho que se há um campo no qual não se trata sequer de perguntar pela mediação, porque a relação com a política está posta, é o campo da educação. Nela, a questão política está presente sem disfarces. No entanto, vejo o país meio assolado pelo pedagogismo, pela idéia de que através da questão pedagógica você vai dar direção para a atividade política. Não é tratar politicamente a educação, mas o que eu chamo de pedagogismo é instrumentalizar a educação para fins políticos. Não é que haja uma politização da educação, mas uma instrumentalização dela .

Ent. - O pedagógico técnico virou uma espécie de canal caboclo do operacionalismo.

Mar. - Exatamente. É como se para o discurso da modernidade científica da elite no poder fosse necessário contrapor 0 discurso da pedagogia popular como antídoto.

Ent. - Como vive isto entre os pedagogos...

Mar. - Mas, em toda parte, os Institutos de Pedagogia se constituem a si mesmos como uma espécie de vanguarda no campo cultural. Esse é o problema que vem preocupando um sujeito como o Paulo Freire. O Paulo Freire está seriamente 
preocupado com essa pedagogização. Eu, de minha parte, me preocupo porque entre os pedagogos são discutidas questões do seguinte teor: se a libertação das classes oprimidas é algo que é feito por elas próprias, isso significa que as classes oprimidas farão o seu trabalho de libertação, desde que elas sejam instrumentalizadas para isto; como não há "o partido" que vai fazer esse papel, os pedagogos serão os substitutos do "partido". Há muito a idéia de fazer dos pedagogos que estão empenhados na questão da educação popular, de fazer deles o elemento organizador das classes dominadas como um substituto, uma forma vicária do partido revolucionário. Isso me preocupa porque o grau de ideologização a respeito das classes dominadas é profundo. Vai-se perdendo de vista, cada vez mais, a dimensão da exploração, em nome, muitas vezes, de nostalgias em torno do "bom povo" que, recebendo instrumentos, realiza sua liberação. É curioso isso, porque há uma apropriação intrumentalizada, por exemplo, do trabalho dos antropólogos. Ora, o que é interessante no trabalho dos antropólogos, pelo menos os que eu conheço, é que eles mostram que há uma consciência popular, que é uma consciência dividida, é uma consciência que sabe e que no entanto sufoca o seu próprio saber através do poder que a ideologia dominante tem sobre ele. Ora, em vez de lidar com a dominação, com o problema de um saber real que é destruído a cada passo pela ideologia dominante, o que o pedagogismo tenta é fazer de conta que essa ideologia dominante não existe e pretende transformar em teoria esse saber imediato que as classes populares têm a respeito delas mesmas. Então, de algum modo, fica a cargo dos pedagogos a transformação qualitativa do saber popular em ação política. Já não é mais uma atitude do tipo da do CPC, porque é muito diferente, o CPC desqualifica a cultura popular. É uma espécie de esforço, através da educação, para dar à prática política um cunho fundamentalmente pedagógico.
Ent. - Você poderia citar autores, gente que está ligada a essa tendência?

Mar. - Olha, no nível de autor, eu conheço pouco. O que eu tenho visto é em termos de bate-papo, quando faço as viagens e me relatam os trabalhos que estão fazendo.

Ent. - E que, tanto é uma prática que recupera, que incorpora e coopta, que ela encontra não o seu reflexo, mas é o seu espelho, que gera esse reflexo, na ação de órgãos como o Projeto Minerva e Mobral. Enquanto o CPC desqualificava o popular, esta prática nova o valoriza, estimula e emula, como forma de incorporar e depois controlar.

Mar. - E o controle é feito de uma maneira muito peculiar. Sob o pretexto de que a espontaneidade e a liberdade popular se manifestam em não importa quais condições, o pedagogo capta em comunidades, associações, pequenas escolas de educação de adultos, enfim, ele capta os anseios do grupo com o qual ele está trabalhando. Ele transforma esses anseios em cartilhas e devolve sob a forma de cartilha o que ele imagina que foi o anseio que ele captou. Então ele devolve para o outro, mas agora já filtrado por seu próprio trabalho pedagógico, aquilo que ele está nomeando como a liberdade do outro. Ora, na verdade, ele está exercendo, sem saber, porque a intenção não é esta (no nível das intenções, a intenção é profundamente libertadora), uma prática de controle. Você fica sabendo tudo que se passa ali, como é realizado, que direções a coisa pode tomar, e você imprime valores nessas direções que você criou. Você dirige o processo e o controla.

Ent. - E o Paulo Freire, nisso aí?

Mar. - Não, o Paulo Freire está muito preocupado com isso, porque depois da experiência que ele teve na África ele tem feito sérias restrições ao método que inicialmente ele tinha, especialmente este aspecto controlador que o método tinha, e no entanto é isso que está sendo muito de- 
senvolvido. Tanto que muitas vezes eu participei de mesas-redondas com ele em que fazia a crítica disso. Ele está muito preocupado de que sua crítica seja uma crítica já meio inoperante porque o método foi interpretado e absorvido na forma anterior que tinha. Um outro fenômeno que é curioso, no caso da intelectualidade, é a tentativa de participar da opinião pública sem ficar fechada no recinto universitário. Só que, enquanto isso era feito através da chamada imprensa alternativa, essa participação no campo da opinião pública era uma participação na qual o intelectual tinha como elemento de controle das suas opinióes apenas ele próprio. Ora, com a desaparição da imprensa alternativa (porque o que há agora, sob a forma dos tablóides, a gente não pode mais chamar de imprensa alternativa, são todas claramente partidárias), sobram alguns jornais da grande imprensa que fazem um jogo interessantíssimo. Interessa a esses jornais aparecerem como jornais liberais e democráticos. Então, eles aceitam, estimulam, solicitam que intelectuais das posições mais divergentes se manifestem desde que assinem seu próprio nome e se responsabilizem pelo que estão dizendo. De tal modo que o jornal pode trazer um editorial o mais reacionário possível e, uma ou duas páginas depois, um artigo progressista. A televisão faz exatamente a mesma coisa. Para um Canal Livre com o governador do Estado (vai ser no próximo domingo), um Outras Palavras com Fernando Henrique, Marilena Chauí e Paulo Singer. Acho que se coloca para os intelectuais brasileiros uma coisa nova que é meditar um pouco sobre a validade ou não dessa interferência sobre o campo da opinião pública através dos meios de comunicação. Esse é um fenômeno novo na medida em que anteriormente eram os profissionais da comunicação, os grandes jornalistas, que ocupavam esse espaço. Esse espaço agora foi of erecido aos intelectuais. Mas ele é of erecido com um número tão grande de restrições e sob tamanho controle que acho que chegou o mo- mento da gente começar a perguntar se vale a pena se deixar instrumentalizar. Isso no momento não é claro para mim. Por um lado, são veículos através dos quais você atinge uma quantidade imensa de pessoas e com um retorno imenso. Há um retorno. Quando eu viajo, as pessoas vêm me procurar para dizer que lêem as coisas que eu escrevo na Folha ou que me viram na televisão e aproveitaram muito. A maioria das pessoas que se dispõe a me ouvir raramente leu os livros que escrevi, no máximo leu "O que é Id eologia", pouquíssimas leram "Cultura e Democracia" e dá pra contar nos dedos os que leram "Da Realidade Sem Mistérios", mas todos, sem nenhuma exceção, são leitores do que escrevo na Folha e no Folhetim. E todos, na rua, na feira, no supermercado, na padaria e no açougue falam comigo sobre o que eu disse em programas de televisão. Então, esse elemento é um elemento paradoxal porque eu imagino que isso deva ocorrer com todos os intelectuais que tenham entrado pela imprensa e pela televisão, que é o de se saberem lidos e ouvidos. No entanto, não que eu queira ser frankfurtiana, mas você é lido e ouvido numa colcha de retalhos tamanha que você se pergunta: o que é que sobra do artigo que você escreveu? O que é que sobra do programa em que você falou? Essa é uma coisa que eu não sei.

Ent. - E até que ponto esse convite e essa proposta para entrar dessa forma na grande imprensa não tem precisamente este objetivo e função? Que a sua contribuição seja um retalho na grande colcha de retalhos?

Mar. - E que isso apareça sob o nome de pluralismo democrático. Essa é uma questão que começa a me preocupar seriamente. Porque enquanto eu escrevia e não imaginava muito que fosse lida, eu tinha muito, com relação ao artigo de jornal, a mesma perspectiva que com o artigo publicado na revista Discurso. E não é verdade, A questão é: o jogo de quem você, 
afinal, está fazendo? Sob a ilusão de que está fazendo o seu próprio papel, não sei se a gente está fazendo o próprio papel e eu começo a revalorizar extremamente a conferência sobre o artigo impresso, a não ser nos momentos em que o artigo tem um recado muito preciso a ser dado, mas, caso contrário, da maneira como eu vinha fazendo, que era escrever praticamente sobre todos os assuntos que fossem surgindo, eu começo a ter minhas dúvidas sobre o serviço que isso presta. Eu acho que presta um serviço, mas provavelmente contrário àquele que eu desejaria. Mas isso é uma dúvida para mim. Ao mesmo tempo em que, cada vez que se apresenta uma oportunidade de você mobilizar sob a forma de um artigo de jornal ou de um programa de televisão todo o acervo de conhecimento filosófico de que você dispõe, a tentação é enorme de ultrapassar o muro da Universidade. Mas eu não sei. Não é muito claro para mim.

Ent. - Eu diria que sou quase tentado a pensar numa insídia do sistema. Como você sabe, o sistema estudou muito comu- nicologia nos últimos anos e os comunicólogos têm uns números cabalísticos mas muito precisos sobre taxa de informação e taxa de saturação na informação; e principalmente na época das suas contribuições no "Folhetim", antes da sua viagem, quando as contribuições eram freqüentes e regulares, me dava uma certa apreensão de que essas contribuições estivessem chegando perto da taxa de saturação em que, daqui a pouco, a Marilena Chauí já não está dizendo mais nada porque está dizendo todas as semanas. É de uma sabedoria enorme, você tem toda razão de estar preocupada.

Mar. - Tanto que, semanalmente, a Folha, a Isto É, o Jornal da Tarde, o Jornal do Brasil, a revista Senhor, a televisão Bandeirantes, a rede Globo, a TV Cultura, as rádios telefonam pedindo artigos, entrevistas, debates. Vocês vêem que eu, este ano, publiquei o artigo sobre a Polônia e sobre o PT, apenas. Mas apareci três vezes na televisão e três vezes no rádio. $\mathrm{O}$ que é absurdo. 